NBER WORKING PAPER SERIES

\title{
INHERITED WEALTH, CORPORATE CONTROL AND ECONOMIC GROWTH: THE CANADIAN DISEASE?
}

\author{
Randall K. Morck \\ David A. Strangeland \\ Bernard Yeung \\ Working Paper 6814 \\ http://www.nber.org/papers/w6814 \\ NATIONAL BUREAU OF ECONOMIC RESEARCH \\ 1050 Massachusetts Avenue \\ Cambridge, MA 02138 \\ November 1998
}

The authors are grateful for helpful suggestions from Juan Alcacer, Daniel Feenberg, E. Han Kim, David Levy, Krishna Palepu, Michael Weisbach, and Luigi Zingales. The views expressed here are those of the author and do not reflect those of the National Bureau of Economic Research.

(C) 1998 by Randall K. Morck, David A. Strangeland, and Bernard Yeung. All rights reserved. Short sections of text, not to exceed two paragraphs, may be quoted without explicit permission provided that full credit, including $(\mathcal{C}$ notice, is given to the source. 
Inherited Wealth, Corporate Control and

Economic Growth: The Canadian Disease

Randall K. Morck, David A. Strangeland, and Bernard Yeung

NBER Working Paper No. 6814

November 1998

Countries in which billionaire heirs' wealth is large relative to G.D.P. grow more slowly, show signs of more political rent-seeking, and spend less on innovation than do other countries at similar levels of development. In contrast, countries in which self-made entrepreneur billionaire wealth is large relative to G.D.P. grow more rapidly and show fewer signs of rent seeking.

We argue that this is consistent with wealthy entrenched families' having objectives other than creating public shareholder value. Also, the control pyramids through which they are entrenched give wealthy families preferential access to capital and enhanced lobbying power. Entrenched families also have vested interest in preserving the value of existing capital. To investigate these arguments, we use-firm-level Canadian data. Heir-controlled Canadian firms show low industry-adjusted financial performance, labor capital ratios, and R\&D spending relative to other firms the same ages and sizes. We argue that concentrated, inherited corporate control impedes growth, and dub this "the Canadian disease." Further research is needed to determine the international incidence of this condition.

Finally, heir-controlled Canadian firms' share prices fell relative to those of comparable firms on the news that the Canada-U.S. free trade agreement would be ratified. A key provision of that treaty is capital market openness. Under the treaty, heir-controlled Canadian firms' labor capital ratios rose, while the incidence of heir-control fell. We suggest that openness, especially of capital markets, may mitigate the ill effects of concentrated inherited control. If so, capital market openness matters for reasons not captured by standard international trade and finance models.

Randall K. Morck

Professor of Finance

University of Alberta

Edmonton, Alberta

Canada T6G 2R6
David A. Strangeland

Associate Professor of Finance

University of Manitoba

Winnipeg, Manitoba

Canada R3T 5V4

\section{Bernard Yeung}

Professor of International Business

University of Michigan

Ann Arbor, MI 48109-1234 


\section{Introduction}

Economic value is created by the efficient allocation of an economy's capital. Much of many countries' capital is proffered to corporations controlled by a small number of very wealthy families. This could be desirable if these families provide optimal corporate management. This paper raises the possibility that the currently observed allocation of corporate control may in fact be suboptimal in such countries.

The basic finding of this paper is that countries in which billionaire heirs' wealth is large relative to G.D.P. grow more slowly than other countries at similar levels of development, while countries in which self-made entrepreneur billionaire wealth is large relative to G.D.P. grow more rapidly than other countries at similar levels of development. We consider several explanations for this finding. First, old wealth may entrench poor management and control pyramids may distort their incentives. Second, a sharply skewed wealth distribution may create market power in capital markets causing inefficiency. Third, entrenched billionaires have a vested interest in preserving the value of old capital and thus in slowing creative destruction. Fourth, old money becomes entrenched through control of the political system, and most especially by rearing barriers to capital mobility. In contrast, substantial self-made billionaires' wealth is observed where such forces are ineffectual and creative destruction occurs.

We use micro-level evidence to support or refute these macro-level explanations. Canadian data is useful for this purpose because the large firms in that country exhibit a large range of ownership structures, with billionaire-controlled and widely-held firms both abundant enough for statistical analyses. Also, the Canada-US free trade agreement causes a useful regime change that generates testable predictions of our proposed explanations.

Our evidence is consistent with corporate control by heirs leading to slow growth because 
of inefficiency due to entrenched corporate control, capital market power, high barriers against outside investment, and perhaps also low investment in innovation. We hypothesis that this "Canadian disease" may be a generalizeable explanation of our basic cross-country finding.

Obviously, further investigation into micro level data for other countries is called for.

\section{The Ownership Structure of Countries}

Table 1 displays the 1993 wealth of Forbes 1,000 billionaire residents by country of residence and scaled by 1993 GDP.' Our sample was constructed as follows. We began with all countries having 1997 GDP greater than US\$1 billion. We drop all post-socialist countries such as China, the Czech Republic, Hungary, Poland and Russia; all countries currently subject to economic sanctions such as Cuba, Iran, and Iraq; the oil sheikdoms Bahrein and Brunei; the tax havens Liechtenstein and Luxembourg; Ethiopia, Kuwait, and Lebanon, which are undergoing postwar reconstruction; Sri Lanka and the Democratic Republic of the Congo, which are currently experiencing civil war; and Bangladesh, Egypt, El Salvador, Ghana, Jordan, Kenya, New Zealand, Nigeria, Saudi Arabia, Syria, Tanzania, and the United Arab Emirates because of missing data.

The final sample contains: Argentine, Australia, Austria, Belgium, Brazil, Canada, Chile, Colombia, Denmark, Ecuador, Finland, France, Germany, Greece, Hong Kong, Iceland, India, Indonesia, Ireland, Israel, Italy, Japan, Korea, Malaysia, Mexico, the Netherlands, Norway, Peru, the Philippines, Portugal, Singapore, South Africa, Spain, Sweden, Switzerland, Taiwan, Thailand, Turkey, the United Kingdom, the United States, and Venezuela.

1. Unfortunately, most studies of economic inequality focus on income distribution; rather than wealth distribution. The typical finding is that economic growth is slower in countries with more uneven income distribution (Fishlow, 1996, Birdsall et al. 1995). Wealth based Gini coefficients appear to be unavailable. We therefore take a practical approach and construct our own proxy for wealth, or capital ownership, concentration. As an innovation in 1997, Forbes included political dynasties ranging from the Suharto to the Windsors in its billionaire list. For the few countries in which these families are present, we use 1997 family wealth. Our results are robust to dropping or including these families. 
[Table 1 about here]

In subsequent econometric work, we drop the United States and the United Kingdom from our sample on the grounds that their corporate ownership structures are highly atypical, in that their large listed companies are predominantly directly held by small shareholders (La Porta et al. 1997). We leave them in Table 1 since they provide useful benchmarks for wealth concentration comparisons.

There is a remarkable degree of variation. The average billionaire wealth is $13.3 \%$ of GDP for the East Asian economies: Korea, Hong Kong, Indonesia, Malaysia, the Philippines, Singapore, Thailand and Taiwan. Hong Kong is the least egalitarian of these, with billionaires holding wealth equal to $36 \%$ of its GDP. The average for Latin American countries in our sample is $4.5 \%$, with Mexican billionaires' wealth the highest, at $12.8 \%$ of GDP. Billionaires are less important in the $\mathrm{OECD}$, where the average is $2.4 \%$. The least egalitarian OECD countries are Greece, Switzerland and Sweden, with billionaire wealth $13.3 \%, 7.7 \%$ and $5.6 \%$ of GDP respectively. This contrasts with $1.1 \%$ for the UK, $4 \%$ for Canada, and just under $4 \%$ for the U.S.

These numbers, large as they are, greatly understate the importance of wealthy families in most economies. La Porta et al. (1998) show that pyramid ownership structures are ubiquitous outside the United States and United Kingdom. In a pyramid ownership structure, a wealthy family controls assets worth vastly more than its own wealth by holding controlling interests in companies, which hold controlling interests in other companies, which in turn hold controlling interests in still more companies. A control pyramid 10 layers high, with $51 \%$ ownership at each level, magnifies a billion dollars of wealth into control over $\$ 840$ billion ( $\$ 1$ billion $\left./ .51^{10}\right)$ worth of corporate assets. Intercorporate cross-holdings and the use of super-voting shares for insiders and non-voting shares for outsiders in many countries further extend and strengthen billionaires' control. An example of 
a fortune extended in this way is that of the Wallenberg family of Sweden. Though their actual wealth fails to get them onto Forbes' billionaire list, the firms they control through a mixture of pyramids, cross-holdings, and multiple voting shares constitute $40 \%$ of the market value of the Swedish stock exchange. ${ }^{2}$ Similarly, firms in the estate of "Lucho" Noboa provide the incomes of about three million of Ecuador's eleven million people. The family's banana operations alone, which account for $40 \%$ of Ecuador's banana exports, generate about $5 \%$ of the country's GDP. ${ }^{3}$ Yet billionaire wealth for Ecuador is zero in Table 1 since the family's actual wealth is less than one billion dollars. If we conservatively take pyramids as multiplying a billionaire family's wealth into control over assets worth ten times as much, billionaire control averages $133 \%$ of GDP in East Asia, $45 \%$ of GDP in Latin America, and $24 \%$ of GDP in the OECD (though this calculation is not applicable in the United Kingdom and especially the United States, where control pyramids are seldom used).

\section{Entrepreneurs, Inherited Wealth and Economic Growth}

Should the ownership structure of a nation's capital, in this context, the capital controlled by different types of billionaires, matter? There are numerous reasons to think it might.

Building a fortune and passing it down to one's descendants might be a powerful motivation for prospective entrepreneurs to build great businesses. Wealthy heirs have the resources and incentives to monitor corporate managers carefully, and so might improve corporate governance. Powerful families, whose fortunes are tied to their nation's economies, might lobby politicians to enact economically rational policies, and might be more successful at this than small atomistic

2. Strom, Stephanie. “In Sweden, A Shy Dynasty Steps Out.” New York Times. May 12, 1996.

3. De Cordoba, Jose. "Heirs Battle over Empire in Ecuador." Wall Street Journal. Dec. 201995. 
businessmen. Wealthy families might act to safeguard competitive and efficient capital markets and institutions. Wealthy families also have the security and the resources to bankroll innovation. Any or all of these factors could lead to a positive relationship between economic growth and billionaire wealth.

However, a negative relationship is also plausible a priori. Since intelligence is thought to be, at best, only partly inherited, an entrepreneur's descendants should regress steadily towards average talent with each new generation. If they value the control that pyramids and the like bestow upon them, they become entrenched, mediocre managers. Their magnified control of capital may also let wealthy families shape prices in capital markets to further their own welfare at the expense of their countries. Also, with their wealth tied up in existing capital, wealthy families may be loath to finance innovations for fear that the ensuing creative destruction might get out of their control. Finally, their corporate control may give billionaire families economies of scale in political rentseeking, and thereby divert public resources to their private goals.

\subsection{Observation}

The actual relationship between a country's capital ownership structure and economic growth is therefore an important but unexplored empirical question. To address this question, we run standard economic growth equations of the sort described by Mankiw (1995), with an extra term at the end:

$$
\frac{\Delta Y}{Y}=\beta_{0}+\beta_{1} \ln \left(\frac{Y}{L}\right)+\beta_{2} \frac{I}{K}+\beta_{3} \ln (E)+\mathbf{b} \cdot \mathbf{C}+\varepsilon
$$

Our dependent variable is economic growth, defined as the average growth rate in real GDP, $Y$, averaged over 1994, 1995 and 1996. The independent variables in such regressions generally 
include the logarithm of each country's 1994 per capita GDP, $\ln (Y / L)$; a physical capital accumulation rate, $I / K$, where $I$ is capital investment and $K$ is the existing capital stock; and a measure of human capital, the logarithm of the average years of education, $\ln (E)$. Our data on investment rates and education levels is for 1990 and 1985 respectively, and is from the World Bank Growth Data used by e.g. Barro and Lee (1996).

To these we add $\mathbf{C}$, a variable or set of variables describing the capital controlled by different types of billionaires in each country. We use the wealth and sources of wealth of each country's billionaires to construct these variables. An alternative approach would be to use wealth GINI coefficients. However, our research question is more about the type of wealthy people in a country than about the degree of wealth concentration per se. Another alternative approach would be based on the fractional ownership in each country's largest corporations. But this approach focusses on the billionaire's equity stakes as a fraction of firm value, rather than their wealth as a fraction of the country's wealth, and so is less useful for our purposes.

We consider two basic types of billionaires, based on Forbes magazine's description of each billionaire and on additional information from Who's Who. The first is self-made business entrepreneurs. These are people who built huge fortunes from nothing or virtually nothing. We define $B$ to be the total wealth of a country's self-made business entrepreneurs and scale this by GDP, denoted $Y$. We thus add $B / Y$ to regression 1 as the first component of $\mathbf{C}$.

The second sort of billionaire we call heirs. We define their total wealth in each country to be $H$, and again scale by GDP, thus adding $H / Y$ as the second component of $\mathrm{C}$ in regression 1 . We have several alternative measures of this variable. We divide billionaires who are not self-made into different categories. Some are clearly not billionaires because of their entrepreneurial talents. These include heirs to great business fortunes and political dynasties. These we call "heirs." Other 
billionaires have inherited substantial fortunes, but greatly increased them. We call them "heirentrepreneurs." The remaining we classify as " probably heirs." This category includes fortunes that appear to be controlled jointly by self-made billionaires and their heirs. This wealth is presumably in the process of being transferred across generations. It also includes some fortunes that we are simply unable to clearly classify because of inadequate documentation.

In Table 2, we consider alternative measures of heir fortunes that include different subsets of the above categories. Our first measure, $H_{l}$, is the wealth of heirs to business fortunes and political dynasties. The second, $H_{2}$, is $H_{1}$ plus the wealth of "probably heirs". The third measure, $H_{3}$, is $H_{l}$ plus "heir-entrepreneurs". Finally, $H_{+}$is $H_{l}$ plus "probably heirs" and "heir-entrepreneurs". The measures $H_{5}$ through $H_{8}$ replicate $H_{1}$ through $H_{4}$ respectively, but exclude "political dynasties." All eight measures give remarkably similar results. ${ }^{4}$ In subsequent tables, we measure heir billionaire wealth by $H_{l}$, fortunes clearly due to either inheritances or political dynasties. We use this measure to minimize the likelihood of contaminating our heir wealth variable with any fortunes that might be controlled by business entrepreneurs. However, this choice turns out to be unimportant: All the analyses in subsequent tables are qualitatively similar if other definitions of heir are used.

Table 2 confirms previous findings that countries tend to have higher rates of economic growth if their initial per capita GDP is low, if their capital accumulation rates are high and (more tenuously) if their general level of education is high. Our added variables reveal a clear pattern. Economic growth is positively associated with self-made billionaire wealth, but negatively associated with billionaire heir wealth. We emphasize that this is after controlling for per capita

4. "Heir-entrepreneur" wealth, "probably heir" wealth, and "political dynasty" wealth, treated as a separate right-hand side variables, resembles "heir" wealth. 
GDP, the rate of capital accumulation, and education.

The effect is economically, as well as statistically, significant. The average rate of GDP growth in our sample is $4.16 \%$ per year. Since the coefficient on heir billionaire wealth over GDP in the first regression is -.292 , going from zero billionaire heir wealth to the $75^{\text {th }}$ percentile, $3.293 \%$ of GDP, is associated with a slowdown of $0.962 \%$ per year, and heir wealth at the $90^{\text {th }}$ percentile, $6.667 \%$, corresponds to a growth slowdown of $1.95 \%$ per year.

\subsection{Further Exploration}

In the following sections, we consider different possible mechanisms by which heir wealth might affect economic growth and consider whether each, in turn, might be empirically rejected. To explore their empirical validity, we utilize firm-level data for Canada. That country is ideal for our purposes because large Canadian firms exhibit a wide range of ownership structures, with enough firms in each category to allow statistical analyses. Firm-level accounting data in Canada is also readily available and reliable. Finally, the US and Canada are, in most aspects, very similar countries. Although natural resources account for a larger share of Canada's GDP, its resources industries and those of the United States are not dissimilar. The two economies have broadly similar factor endowments, and employ virtually identical technology and human capital in similar institutional frameworks. Their corporate sectors differ markedly only in that the ownership structures of their largest firms are radically different. Thus, the U.S. economy provides a useful benchmark.

Table 3 displays the ownership structure of the 246 publicly traded firms in the list of the top 500 Canadian firms by sales in 1988, as reported in the Financial Post Surveys for that year. (We use 1988 data here because free trade with the United States changed the corporate landscape 
subsequent to that. We return to these changes below.) We follow Canadian corporate governance laws and define a controlling shareholder as anyone with a stake that bestows $20 \%$ voting power or more. This is a restrictive definition of control by U.S. standards, where much smaller stakes are thought sufficient to allow control.

Only 53 of the largest 246 public Canadian firms are widely held by this definition. This rises to 67 if publicly traded subsidiaries, subsidiaries of subsidiaries, and so on, of widely-held firms are added. The average stake of the largest shareholder is about $50 \% .^{5}$ This contrasts starkly with the United States, where Demsetz and Lehn (1985) report that the combined holdings of the largest five shareholders average less than $25 \%$.

We proceed by dissecting Canadian firm-level data to see if our explanations apply to that country. Obviously, firm-level analyses in other countries are needed before reliable generalizations are warranted. We also recognize that this leaves the issue of causality open, as future researchers may consider other mechanisms than those we have evaluated.

\section{Inherited Wealth and Corporate Control}

In the United States, firms whose boards are dominated by a controlling family are beginning to attract the attention of corporate governance critics. Refering to family dominated public companies, Jon Lukomnik, the deputy controller for pensions of New York City, commented: "When you look at really abusive companies, you tend to find them." U.S. family firms recently targeted by shareholder rights activists include Ethyl Corporation, where Chairman and C.E.O. Bruce Gottwald's $17.7 \%$ stake brings directorships for his two sons, a brother and a nephew.

5. The degree of concentration of Canadian ownership is greatly understated because the other 254 firms in the top 500 list are privately-held, and so must be dropped from our sample for lack of data.

6. See "Boards Cut Out of Family Trees" International Herald Tribune, Feb. 2, 1996, pages 13 and 17. 
Archer Daniel Midlands, Paccar Inc., the New York Times, and The Gap have attracted similar attention. $^{7}$

Stulz (1988) and Shleifer and Vishny (1989) develop theoretical frameworks describing how corporate governance might suffer when U.S. firms are unable to throw off substandard, but entrenched managers. In this section, we argue that such problems may be many times worse in other economies.

\subsection{The Divergence of Interests in Control Pyramids}

Outside the United States, moneyed families often leverage their wealth into control over corporate assets worth far more. La Porta et al. (1997) show that this is achieved primarily through the use of control pyramids. An example of a control pyramid is the group of firms controlled by the Canadian billionaires Edward and Peter Bronfman. They own Broncorp Inc., which controls HIL Corp. with a $19.6 \%$ equity stake. HIL owns $97 \%$ of Edper Resources, which owns $60 \%$ of Brascan Holdings, which owns $5.1 \%$ of Brascan, which owns $49.9 \%$ of Braspower Holdings, which owns $49.3 \%$ of Great Lakes Power Inc, which owns $100 \%$ of First Toronto Investments, which owns $25 \%$ of Trilon Holdings, which owns $64.5 \%$ of Trilon Financial, which owns $41.4 \%$ of Gentra, which owns $31.9 \%$ of Imperial Windsor Group. ${ }^{8}$ The Bronfmans' actual equity stake in Imperial Windsor works out to $0.03 \%$, yet they have full control of it, and of all the other firms in the pyramid above and beside it. This is because they either own more than $50 \%$ of the stock at each stage, or control more than $50 \%$ of the votes via super-voting shares, intercorporate cross-holdings, or other arrangements that reduce the minimum size of a control stake. This branch of the

7. Ibid.

8. Directory of Inter-corporate Ownership. Statistics Canada. Various Issues. 
Bronfman family controls several hundred firms in this way.

More formally, a simplified control pyramid can be thought of as an arrangement where a wealthy family owns fraction $\alpha \in(0,1)$ of firm $A$, which owns fraction $\alpha$ of firms $B_{i}$, which each own fraction $\alpha$ of firms $C_{i}$, and so on.

Such a control pyramid leverages a family's wealth, $\omega$, into control over corporate assets, ९, worth many times more. For example, let firm $A$ be worth $\$ 1$ million. It owns fraction $\alpha$ of each of the $\$ 1$ million firms $B_{l}$ and $B_{2}$. Firm $B_{1}$ then owns fraction $\alpha$ of the $\$ 1$ million firms $C_{1}$ and $C_{2}$, and firm $B_{2}$ owns $\alpha$ of $C_{3}$ and $C_{4}$. These can then own eight firms worth a million dollars each, and these in turn can own sixteen million dollar firms. If one vote per share stock is used, $\alpha$ must exceed $50 \%$. If differential voting shares, intercorporate share holdings, or other irregularities are allowed, $\alpha$ can be much lower, and the rate at which divergence of ownership from control grows with each additional layer is larger.

If fractional ownership $\alpha$ is required for control, the value of the assets under a family's control is $\odot$ and the family's wealth is $\omega$,

$$
\rho=\Delta \omega
$$

where we define the pyramid multiplier to be

$$
\Delta \equiv \frac{1}{\alpha^{n}}
$$

For example, if $\alpha$ is $1 / 3$ and a family used a 6 layer pyramid to control its actual physical assets, it can leverage one billion dollars of wealth into control over $3^{6}$ or $\$ 729$ billion in corporate assets. ${ }^{10}$

9. Directory of Inter-corporate Ownership. Statistics Canada. 1998.

10. In practice, $\alpha$ may be different in each level of the pyramid and in each chain of control. A more general formula for the pyramid multiplier of the control chain $\left\{\alpha_{l j}, \alpha_{2 j}, \ldots \alpha_{n g}\right.$ linking firm $j$ to the family firm $n$ levels above is $\Delta_{j}=\left[\prod_{i=1}^{n} \alpha_{i j}\right]^{-1}$ and the analogue of equation 2 is correspondingly more complicated. 


\subsection{Billionaires' Objectives and Public Share Value}

Pyramids generate a divergence of interests between controlling shareholders and other shareholders analogous to that noted by Jensen and Meckling (1976) between managers and shareholders, but more extreme. Jensen and Meckling showed that if a manager, who owns fraction $\alpha \in[0,1]$ of an equity financed firm's stock, destroys $\$ 1$ worth of corporate assets to receive personal benefits worth $\gamma \in[0,1]$, he is better off as long as $\gamma>\alpha$.

In a pyramid, the divergence between control and actual ownership is potentially much worse than in Jensen and Meckling's example. The divergence is essentially compounded once for each pyramid level that separates the firm in question from the family firm that holds ultimate control. The family's welfare is advanced when it spends one dollar of corporate wealth in a pyramid company it controls to gain $\gamma<1$ in personal benefits if $\gamma>\alpha^{n}$. Again, differential voting shares, golden shares, and other devices allow control to be exercised with $\alpha<50 \%$ at each level, so the divergence of ownership from control rights can be even more extreme. Since $\alpha^{n}$ approaches zero as $n$ becomes large, value destroying consumption of corporate resources becomes more attractive as the number of levels in the control pyramid rises. ${ }^{11}$

Examples of such consumption of corporate resources are abundant. Controlling families may confiscate corporate property for their personal use. They may interfere in corporate decision making to benefit themselves or their friends, to advance pet projects, or to push political goals. They may use transfer pricing to shift income from publicly traded firms they control to private firms they own outright, from firms low in control pyramids to firms near their apexes, or from firms they control via super-voting shares to firms in which they actually own a majority of the stock.

11. For more formal and complete models of corporate pyramids, see Bebchuk and Zingales (1998), Bebchuk, Kraakman, and Triantis (1998) and Wolfenzohn (1998). 
Such transfer pricing can be accomplished via payments for intermediate goods, the private placement of one firm's securities with another, royalty payments for patent or brand name use, captive insurance subsidiaries, or any number of other channels.

In some cases, the family patriarch may use corporate resources to advance a particular political or social view. For example, when the Wallenberg family's top professional manager, Percy Barnevik, told a New York Times reporter, "If we can't get value, we will sell out," indicating that weak Wallenberg firms might be sold, a surprised Peter Wallenberg explained "We would go to very great lengths to resuscitate a company. Whatever he might have said is still a matter of interpretation." In the same article, Anders Scharp, vice-chairman of the Wallenberg flagship, Investor's AP, quipped "It's family values versus shareholder values."' When the family patriarch uses corporate resources he controls, but does not fully own, to pursue an agenda with which shareholders do not agree, a mis-allocation of resources can result. The family patriarch does not bear the full economic costs of his agenda, but the shareholders and the society at large do.

The potential for such prima facie mis-allocations is a central concern of corporate governance law outside the United States. ${ }^{13}$ For example, Canadian corporate governance law contains strict regulations about the disclosure of "related party transactions" and about minority shareholders' rights. Officers and directors are expected to treat all shareholder equally, rather than simply to safeguard the shareholders' presumably identical interests in value maximization, as in the U.S. However, a recent study of Canadian corporate governance concluded that these protective

12. Almar Latour and Greg Steinmetz. 1998. "Investor AB Chairman Tries Balancing Family's Values With Shareholder Values." The Wall Street Journal Interactive Edition. May 18.

13. See Daniels and Morck (1996). 
measures are inadequate. ${ }^{14}$

\subsection{Entrenched Family Control}

Most students of psychology agree that intelligence is, at best, only partially hereditary. Since entrepreneurial ability is presumably one dimension of intelligence, successive generations of heirs to a business entrepreneur's fortune should, on average, exhibit abilities that regress steadily towards the population mean. Entrenched family control, therefore, leads to an increased probability of mediocre management with each successive generation unless the family either delegates decision making to professional managers or is genetically very lucky.

Consistent with the argument that they value control, many wealthy families have difficulty accepting professional managers. In 1995, Stanley Heath resigned after only one year as CEO of Bata Inc., a multinational shoe store chain. The Czech-Canadian Bata family had hired him to usher in fundamental changes, and then, according to the Toronto Globe and Mail, decided they did not like the changes after all. ${ }^{15}$ According to the New York Times, Swedish billionaire Marcus Wallenberg repeatedly denounced his son Peter as having "neither the intelligence nor the vision to head the family businesses."16 In 1982, near the end of his life, Marcus tried to position Volvo chairman Gyllenhammer, a professional manager, to take his place. Peter quietly bought shares in the relatively widely-held Volvo until he had enough leverage over Gyllenhammer to force him out of the Wallenberg companies. Peter is now the undisputed patriarch of the Wallenberg business

14. See Daniels and Morck (1996). In a country where a few large shareholders control most corporations through pyramids, super-voting shares, or other means, there is little if any opportunity for managers to ignore the large shareholders' wishes. Shleifer and Vishny (1988) convincingly argue that large shareholder oversight in the U.S. should prevent managers from pursuing their self-interest at the shareholders' expense. In many other economies, such a salutary view of large shareholders sounds naive, or even disingenuous.

15. Heinzl, John. "Bata CEO Quits After Only a Year, in Shakeup at Top." Toronto Globe and Mail, October 7, 1995.

16. Strom, Stephanie. "In Sweden, A Shy Dynasty Steps Out" New York Times. May 12, 1996, page 12F. 
group, which remains a strong and important part of the Swedish economy.

This unwillingness to cede power to professional managers means the questions of succession can also adversely affect corporate governance. Prolonged internecine power struggles can paralyse family corporate groups. For example, the Canadian McCain corporate group was maimed by a festering dispute between the ruling brothers, Wallace and Harrison, over whose son should succeed them. ${ }^{17}$ In Ecuador, deceased banana billionaire "Lucho" Naboa's second wife, Mercedes, and his second son from his first marriage, Alvaro, fought an unseemly struggle for control of his corporate group. Apparently someone even hired thugs to steal copies of the will hidden in New York. Meanwhile, the family's firms drifted. ${ }^{18}$ Different families have attempted to avoid such problems in different ways. The Eaton family of Canada defused succession problems by bringing increasing numbers of Eatons into managerial positions with each successive generation. The family's flagship company is currently attempting a bankruptcy restructuring. The Bronfman family has used a more Darwinian approach, letting contending heirs compete to be named Dauphin. Having no immediate successor can be as big a problem as too many possible successors. When patriarch Ted Rogers of Rogers Communications retired in 1994, his children Lisa, then 27, and Edward, 26, where regarded as heirs apparent who would take control after another ten years or so of training. Interim managers were unable to exercise leadership in this situation, and Ted Rogers returned despite a triple by-pass and eye surgery. ${ }^{19}$

Many aging founders have difficulty even contemplating their retirement, let alone readying their corporate groups for professional managers or for the next generation of the family. Despite

17. Gord McLaughlin. "In the Name of the Father and the Son" Financial Post. September 301995 , page 14.

18. De Cordoba, Jose "Heirs battle Over Empire in Ecuador" Wall Street Journal, September 20 1995. Who hired the thugs is unclear, though the Wall Street Journal reported that the N.Y.P.D. suspected a family power play. .

19. Gord McLuaughlin. "What If He Dies?" Financial Post. September 231995 page 14. 
a public declaration of his intention to retire at 65, Paul Desmarais, patriarch of Power Corporation, the key company of one of Canada's largest control pyramids, remains firmly in control. The Financial Post reports an anonymous possible successor as saying "I don't know how to get rid of dad's old boys. They don't understand present competitive life, customer service, and just-in-time delivery. They're just sort of performing an activity, like having coffee every morning But I can't do anything about it because dad won't let me fire them." ${ }^{20}$

All of these examples are qualitatively similar to entrenched management in US firms with insider ownership above a certain threshold, as modelled by Stulz (1988) and Shleifer and Vishny (1989). That is, the family appointed managers of firms in control pyramids are not vulnerable to removal by public shareholders through hostile takeovers, proxy contests, or other mechanisms, as only a minority of the stock of any individual firm is in public hands. The difference is that the entrenchment of these family dynasties in other countries is hereditary and affects the dozens or hundreds of companies in family control pyramids.

\subsection{Family Control and Firm Performance - The Worst of Both Worlds?}

In the United States, many studies have found that the divergence of interests problems, like those described in section 4.2 , reduce shareholder value for very widely-held firms; while management entrenchment problems, like those described in section 4.3, reduce shareholder value for relatively closely-held firms. ${ }^{21}$ We have shown how pyramids can magnify the divergence of interests between controlling families and the public shareholders of pyramid companies. We have also argued that pyramids entrench hereditary management, regardless of competence, in more

20. All these examples are from Gord McLuaughlin. "In the Name of the father and the Son" Financial Post. September 301996 pages 14-15.

21. See Stulz (1988), Morck et al. (1988), McConnel and Servaes (1990) and many others. 
complete control over more corporate assets than is possible with the same family wealth in the United States. ${ }^{22}$ Firms in pyramids are thus simultaneously potentially subject to the worst of both problems in terms of public shareholder value. ${ }^{23}$

Of course, if the family provides superior management in firms it controls, this may negate all of the above problems. Khanna and Palepu (1998a, 1998b) argue that skilled corporate management is scarce in India, and that family corporate groups organized as pyramids are, on net, beneficial because they expand the scope on which the families' management skills are applied. This may be true in many cases, including the Bronfman and Wallenberg corporate groups mentioned above. ${ }^{24}$ Nonetheless, pyramids and the leverage they introduce between ownership and control unquestionably create latitude for immense corporate governance problems.

To investigate these issues, Tables $4 \mathrm{a}$ and $4 \mathrm{~b}$ compare the performance of Canadian firms according to the type of controlling shareholder they have. The categories of controlling shareholder we consider are analogous to those in the previous section. Firms in pyramids are defined as having the same controlling shareholder as the firm at the pyramid's apex. We divide firms into the following categories: Firms without control blocks of $20 \%$ or more are called widely-held. Firms controlled by descendants of their founders are called heir-controlled. Firms controlled by their founders are called business entrepreneur-controlled. In some comparisons, we use a category

22. Control pyramids are essentially unknown in the United States. We suspect that this is because that country taxes dividends paid by one corporation to another. In contrast, Canada and most other countries with which we are familiar, tax only dividends paid to people. Intercorporate dividends are tax-free income for the recipient firm. Clearly, pyramid control structures become prohibitively expensive when intercorporate dividends are taxed. Public finance and tax economists seem not to have appreciated the corporate governance implications of dividend taxation policies.

23. Note that some discussions of managerial entrenchment assume managers gain pure utility from control. This assumption is not necessary. If rent-seeking power is proportional to assets controlled, rather than wealth; and rentseeking allows those with control to pursue their self-interest, managers and large shareholders should value control as a means for increasing their consumption.

24. Daniels et al. (1995) find than Bronfman pyramid firms performed no worse than other similar firms, but appear to follow higher risk strategies. 
called all other domestic private sector. This group is different in each comparison, and includes all private sector firms in our full sample less the firms to which they are being compared. For example, in a comparison of heir-controlled firms versus all other private sector firms, the latter include all the firms listed in Table 3 for which data are available except heir-controlled firms, government-owned firms and foreign-owned firms.

We use four alternative measures of firm performance: return on assets, return on sales, real growth in total sales, and growth in number of employees. Return on assets and return on sales are defined as income + taxes + interest + depreciation over total assets and total sales, respectively. Data for these variables is from the Report on Business database. In analyses like these, controlling for industry differences is important. Unfortunately, many large Canadian firms have no comparable rivals within Canada. We therefore use two methods to control for industry norms: Table 4a uses U.S. three digit industry averages, constructed from Compustat data as proxies for Canadian industry benchmarks, while Table $4 \mathrm{~b}$ uses US firms of approximately the same size and age as our Canadian firms and in the same 3 digit industry. ${ }^{25}$ Canadian corporate groups with consolidated balance sheets are compared to diversified US conglomerates. Because the US and Canadian economies are broadly similar in most dimensions, except for ownership structure, such comparisons are legitimate. To smooth the performance indicators, we consider medians of each from 1984 through 1989 . We define firm size as total 1988 sales and firm age as the number of years between the initial incorporation year and 1988, as listed in the Financial Post surveys or in corporate histories.

Table 4a shows the values and significance levels of dominant shareholder type dummies $\delta_{i}$ in regressions of performance, $p$, relative to US industry average benchmarks, $\bar{p}$ and with 25. See the Data Appendix at the end of the paper for details. 
controls for firm size and firm age. For example in a test of heir-controlled firms vs. self-made business entrepreneur-controlled firms, $\delta_{i}$ is one if the dominant shareholder is an heir and zero if the dominant shareholder is an entrepreneur. The regression

$$
p-\bar{p}=\beta_{0}+\beta_{1} \log (\text { firm size })+\beta_{2} \log (\text { firm age })+\beta_{3} \delta
$$

is then run across the two subsamples of firms and the values of the coefficient $\beta_{3}$ are recorded in Tables $4 \mathrm{a}$ for each pair of subsamples. Table $4 \mathrm{~b}$ contains the values and significance levels of the same regression coefficient but with the benchmark, $\bar{p}$, the analogous performance measures for a US firm in the same 3 digit industry and of the same size and age as the Canadian firm in question. $^{26}$

\section{[Table 4a and $b$ about here]}

We can summarize the pattern findings in Tables $4 \mathrm{a}$ and $4 \mathrm{~b}$ as follows. Control by heirs is associated with lower returns on sales and assets and with growth that is less than or equal to that observed in other comparable firms. ${ }^{27}$ In contrast, founder control is associated with earnings lower than in widely-held firms, but higher than in heir-controlled firms, and with growth greater than or equal to that of widely-held firms and that of other firms in general. The pattern of signs and significance levels is similar regardless of whether we include firms in control pyramids or only consider firms directly owned by the shareholders in question. This evidence is consistent with the

26. We continue to include age and size controls in Table $4 \mathrm{~b}$ because the relationship between relative performance and ownership may be different for firms of different sizes and ages. In fact, the logarithm of firm age retains its significance in many of the regressions of Table $4 \mathrm{~b}$.

27. We need to be careful about our inference that heir-controlled firms have lower average returns on assets. R\&D spending is a minus item in the calculation of after-tax operating income since it is part of general, sales and administrative expenses; but does not enter into the calculation of total assets since it is expensed rather than depreciated. A precise adjustment is difficult since the disclosure of R\&D is optional under Canadian G.A.A.P. However, only the numerator of the return on sales figures should be affected by this problem. As a rough check of whether or not R\&D is biasing our results, we first estimated the relation of reported R\&D to heir ownership. R\&D is negatively correlated to heir ownership. If actual R\&D mirrors reported numbers, this effect strengthens, rather than weakens, our return on sales and assets findings. 
hypothesis that widespread corporate control by heirs is, at least partly, responsible for the reduced economic growth for countries with large wealth holdings by heirs shown in Table 2. It does not, however, substantiate our concern that control pyramids might worsen the damage they do.

\section{Inherited Wealth and Capital Market Power}

In some countries, control pyramids and other mechanisms give billionaire families control over substantial fractions of their country's capital assets. This could conceivably translate into monopoly and monopsony market power in their domestic capital markets.

\section{$5.1 \quad$ Limited Sources of Capital for Entrepreneurs}

An efficient microeconomic allocation of capital requires that the risk adjusted cost of capital be the same for all firms. The legal, regulatory, and institutional structures of many countries arguably channel capital to certain firms and limit other firms' access to capital.

First, many countries stock market regulations are such that entrepreneurs find equity IPOs unattractive sources of capital (La Porta et al., 1997). Private equity financing in the form of venture capital is primarily a US. phenomenon. Although other countries are attempting to foster venture capital financing, their scale remains limited. ${ }^{28}$ In Canada, the federal government has been providing generous tax incentives to create a venture capital industry controlled by labor unions. ${ }^{29}$ In both Europe and Canada, government-run funds play large roles in the venture capital business, but these initiatives tend to confuse venture capital financing with subsidies to depressed regional

28. See "Adventures with Capital" The Economist, Jan 25, 1997, pp. 17-18. See also "Finance and Economics: Europe's Great Experiment" The Economist, Jun 13, 1998, pp. 67-68.

29. Management expense ratios in these funds can reach $10 \%$ per year, and their voting structures lock in union control. See Richard E. Austin "Labour-sponsored venture funds" Canadian Shareowner, Mar/Apr 1996. 9(4) p. 9. 
economies. $^{30}$

Second, entrepreneurs' access to debt financing is often limited. Public debt issues are unavailable to small, start-up firms. The junk bond industry in the US changed this, starting in the 1980s, but has yet to spread outside that country in any significant way. ${ }^{31}$ Banks in most countries prefer to lend to large, established borrows. Although the large Canadian banks have recently begun to boast of their lending to small businesses, they still require substantial collateralizable assets - a rarity among entrepreneurial firms whose main asset is usually the intangible ideas of the entrepreneur (MacIntosh, 1994). If billionaire families either control banks outright or influence them through political rent-seeking more effectively than can entrepreneurs or the representatives of widely-held firms' shareholders, a redirection of capital might occur. ${ }^{32}$

Third, government industrial policies in many countries direct capital towards large, established businesses. Plausibly, these firms are more able to lobby for subsidies. Their stability is also more likely to be the object of lobbying by organized labour. For example, Beason and Weinstein (1996) document that the (in)famous Japanese post-war industrial policy, by and large, subsidized unprofitable established industries. Also, until very recently, the Korean government had an explicit policy of orchestrating generous low cost bank loans to large family-controlled Chaebol corporate groups. The result was an average debt to equity ratio of 4.0 in 1996 and relentless capital expenditure growth by these firms. The same year, Chaebol firms averaged a one percent return

30. See Gordon C Murray (1998) "A Policy Response to Regional Disparities in the Supply of Risk Capital to New Technology-based Firms in the European Union: The European Seed Capital Fund Scheme" Regional Studies, 32(5) July, pp. 405-419. See also Andrea Best and Devashis Mitra (1997) "The Venture Capital Industry in Canada" Journal of Small Business Management, 35(2) April, pp. 105-110.

31. See Hagger, Euan “Will Europe get its high yield market?" International Bond Investor, April 1997, pp. 21-32.

32. In section 7 below, we argue that such a differential investment in rent-seeking might well exist. 
on equity. ${ }^{33}$ A key part of the IMF's ongoing criticism of Asian "Crony Capitalism" is that established firms have too ready access to capital while new entrants cannot raise money locally.

Finally, firms in many countries have been prevented from obtaining foreign capital by restrictions on inward investment flows. Explicit policies to deter both FDI and inward foreign portfolio investment were especially common in emerging markets (Kim and Singal, 1997). Interestingly, many of the countries in our sample with the highest heir-controlled wealth had explicit share classes or industry sectors that were unavailable to foreigners, ceilings on foreign shareholding or mandatory long holding periods for foreign investors, at least until quite recently. These include Argentina, Chile, Columbia, Greece, Indonesia, Korea, Malaysia, the Philippines, and Thailand. Except for closed-end funds, Taiwan's stock market was closed until 1991, after which foreigners were allowed to invest up to a $10 \%$ ceiling. This was only raised to $15 \%$ in 1995 . Even advanced countries have regulations hindering foreign portfolio investment. For example, Japanese firms could not issue bonds to foreigners until quite recently. Even Canada, under Pierre Trudeau, made local firms' access to foreign direct investment contingent on bureaucratic approval.

These distortions might lead to more aggressive use of capital by family pyramid firms than by other firms. The absence of a well-developed venture capital market impedes entrepreneurial firms, but not established family firms. If billionaire families are better at lobbying for subsidies than entrepreneurs or representatives of the shareholders of widely-held firms, a differential access to capital also might ensue. Also, if families are over-optimistic about their management abilities, the greater divergence of interests and entrenchment problems in pyramid firms (discussed in section 4) might allow them to overexpand more aggressively than would be prudent for a widelyheld firm. If the initial complement of large firms are members of family pyramids, barriers to 33. For a detailed financial analysis of Korean public firms in the 1990 s, see Kim (1998). 
capital inflow arguably lock in control by those firms, preventing entrepreneurial firms and widelyheld firms from rising to challenge them.

\subsection{Limited investment opportunities for savers}

Economic efficiency also requires free competition for savers' money. Again, the legal, regulatory and institutional structures of many countries severely restrict savers' portfolio choices.

Given the prevalence of billionaire control, savers in many countries have little choice but to hold the stocks of billionaire-controlled companies in their portfolios. These problems afflict investors in most countries other than the U.S. and U.K. Even in Canada, only 53 of the top 500 firms are widely held (see Table 3). Since these do not span all the industries in the Canadian economy, a diversified portfolio of large widely-held Canadian firms is not possible.

The same lack of choice for savers applies to debt. Until recently, Japanese corporate bonds were unavailable to domestic investors in that country because regulations forced firms to use bank debt. Even now, only bonds in highly profitable large firms are available. In Europe, legal access to foreign corporate bonds only developed recently, although the Eurobond market may have provided informal access for wealthy savers. Bank savings in Europe are generally intermediated investments in larger established local firms, as banks in the main lend money to these firms or to governments. Many countries' industrial policies are also essentially schemes to channel bank and postal savings to chosen firms.

Finally, barriers against investing abroad have been ubiquitous throughout the world in recent decades, and appear quite resilient to liberalization. To "manage" their exchange rates, "insulate" their macro-economies from external influences, and prevent the "sterilization" of their monetary policies, many countries have instituted capital control measures that restrict domestic 
savers' freedom to invest outside of their home markets. Foreign portfolio investment by residents was banned in Argentina from 1983 to 1990, until 1990 in Chile, until 1994 in Greece. It remains tightly restricted in Korea (Kim and Singal 1997) and is illegal in Colombia and India. Other countries use regulatory hurdles or tax disincentives to discourage capital outflow. For example, Canada currently limits tax-free retirement savings accounts and pension funds to $20 \%$ foreign content.

These restrictions on savers' choices might allow large, existing firms to access capital at monopsony prices. Since family pyramid firms are all controlled by the same party (the family), they are better able to realize such market power than are collections of independent widely-held firms, even if the individual firms are otherwise similar.

Of course, restrictions on savers' portfolio choices and on entrepreneurs' financing options can, and often do, exist simultaneously. Thus, capital markets can be subject to both monopoly and monopsony distortions simultaneously, the favoured parties being the established large firms, many of which are controlled by local billionaire families.

\subsection{Corporate Control and Capital Intensity}

To test for differential access to capital, we look again at large Canadian firms. Canada's restrictions on the inflow and outflow of capital were relatively mild compared to those of many other countries. We therefore are using data from a country in which the likelihood of finding statistically significant results is relatively low.

We cannot estimate firm-level costs of capital because of the intricate web of intercorporate financial agreements typical in large family-controlled corporate groups. We can, however, ask whether large heir-controlled firms use labor less intensively relative to capital than do other 
comparable firms. If they do, this would be consistent with these firms having preferential access to capital. Our sample is again the set of large Canadian firms described in Table 3.

We also examine labor to sales ratios, which is an indirect indicator of capital utilization. If a firm has a lower labor to sales ratio than other comparable firms, it is less labor intensive, and is therefore plausibly more capital intensive than its peers. Of course, an extremely inefficient firm might have both higher labor to sales and capital to sales ratios than its peers, muddying inferences about labor to capital ratios. Despite this and because accounting asset measures can be highly problematic, the labor to sales ratio may still be more informative, even though it is only indirectly related to the cost of capital.

The dependent variables in our regressions are thus labor to capital ratios and labor to sales ratios. As in Tables $4 \mathrm{a}$ and $4 \mathrm{~b}$, we use two methods of adjusting for industry, firm size, and firm age. First, we run regressions analogous to those in Table $4 \mathrm{a}$, and second, we use matched pairs analogous to the analysis in Table $4 \mathrm{~b}$.

[Table 5 about here]

Table 5 shows that large Canadian firms controlled by heir billionaires have significantly lower labor intensity than entrepreneur-controlled firms, widely-held firms, and other firms in general. These differences are most consistently significant when we include pyramid firms. In contrast, entrepreneur-controlled firms have higher labor intensity than heir-controlled firms, widely-held firms, and other firms in general. These findings are consistent with heir-controlled firms having access to lower cost capital, and with pyramid control structures facilitating this access. ${ }^{34}$ Recall that Canada's capital market distortions and barriers are relatively benign compared

34. It is also consistent with other stories, however. For example, Hoshi, Kashyap and Scharfstein (1990) argue that intercorporate transfers in Japanese corporate groups reduce firm default risk and therefore reduce group firms' costs of capital. 
to those of many other countries. The fact that we find significant results in that country raises the possibility of more severe capital mis-allocation elsewhere, and suggests that relatively low barriers to capital flow can be potent.

\section{Inherited Wealth and Innovation}

Unsurprisingly, established firms have been shown to be unsupportive of radical innovations (Betz, 1996). Indeed, entrenched managers, including heirs, plausibly have a vested interest in blocking innovation (Acs et al. 1995). This should be particularly so for entrenched billionaires, as their wealth is due to existing capital, the value of which creative destruction destroys. We therefore conjecture that heir-controlled firms spend less on innovation than other comparable firms. Moreover, in economies where heir-control is extensive, economy wide aggregate enterprise spending on R\&D should be low.

[Table 6 about here]

Table 6 contains regressions analogous to those in Tables $4 \mathrm{a}$ and $4 \mathrm{~b}$, but explaining R\&D spending. These regressions are more problematic than those in Tables 4 and 5 for several reasons. First, R\&D has skewed distributions, bounded below at zero. We correct for this by using limited dependent variable regression techniques. Second, Canadian G.A.A.P. differs from US accounting rules in that it lets companies freely choose whether or not to report their R\&D. This makes $R \& D$ comparisons with US firms difficult to interpret, since Canadian firms may strategically report R\&D spending. We industry-adjust our Canadian firms' $R \& D$ spending by subtracting the $R \& D$ spending of an industry, size and age matched US control firm. These adjustments are problematic because of intrinsic data problems, so we also report regressions with no industry adjustments. Unfortunately, adding industry dummies is not feasible given the sample sizes. 
Column 6.1 is a logistic regression of a dummy variable (one if the firm reports R\&D and zero otherwise) on ownership type and our firm size and firm age controls. Column 6.2 displays coefficients from a tobit regression of unadjusted $R \& D$ spending over sales on the same right-hand side variables. We scale R\&D by sales to avoid heteroskedasticity. Regressions 6.3 and 6.4 are analogous to 6.1 and 6.2 , but use matched US firms to benchmark R\&D spending. Regressions 6.3 is an ordered logit, where the dependent variable is two if the Canadian firm reports $R \& D$ but the US match does not, one if both either do or do not report $R \& D$, and zero if the match reports $R \& D$ but the Canadian firm does not. Regression 6.4 uses R\&D over sales for the Canadian firm minus R\&D over sales for the US match, and so can be estimated using OLS.

The results in Table 6 are broadly consistent with the hypothesis that heir-controlled firms invest less in innovation than comparable entrepreneur-controlled and widely-held firms. In contrast, Canadian entrepreneur-controlled firms and widely-held firms invest roughly comparable amounts in innovation.

Our second conjecture is that economies in which heir control is extensive tend to have less private sector spending on innovation. To test this, we correlate private 1993 private sector $R \& D$ spending, scaled by GDP, with billionaire entrepreneur and billionaire heir wealth, as in Table 2, across countries. The first column of Table 7 shows that enterprise R\&D spending is negatively correlated with heir wealth $(p$-value $=.13$ ). Since richer countries plausibly have higher R\&D spending, we consider a multiple regression of private enterprise $R \& D$ that controls for per capita GDP. Heir wealth draws a negative and highly significant coefficient. Surprisingly, we also find that entrepreneur billionaire wealth is negatively correlated with private enterprise $R \& D$ spending (p-value $=.16)$ and that the corresponding regression coefficient is negative and marginally significant $(p$-value $=.10)$. We are unable to explain this result. 
In summary, we find that Canadian heir-controlled firms indeed appear less innovative than other firms. A cross country regression also shows that countries with extensive heir wealth have less aggregate private sector spending on innovation. These findings are consistent with our conjecture that heirs favor the status quo.

\section{Inherited Wealth and Market Barriers}

We have argued above that heir-controlled firms are relatively unprofitable, but that the heirs who control them are entrenched. Their strong economic position is due to their heritage and their controlled firms' prominence as capital users and suppliers, not their abilities to manage or innovate. Given this, billionaire heirs are likely to see both innovation and openness as potential threats to the status quo, which favors them. We have shown above that heir control is associated with less innovation. In this section, we explore whether billionaire heir control is also related to explicit barriers to entry protecting product and capital markets.

Control pyramids potentially create incentives for controlling families to invest in excess political lobbying. Pyramids let controlling families lobby using the resources of firms low in their pyramids, whose profitability is relatively unimportant to them. This means the wealthy families can, in essence, use other people's money to lobby for policies that preserve their positions. For example, for the owner of a privately held firm to justify spending $\$ 1$ on lobbying, he (or his firm) must gain $\gamma \geq \$ 1$ in benefits. In contrast, the controlling shareholder in a pyramid $n$ levels high with control stakes of $\alpha$ at each level need only gain benefits worth $y \geq \alpha^{n}$ to him (or the apex firm) if he uses $\$ 1$ of the resources of a firm at the base of the pyramid for lobbying. In general, the controlling shareholder of a such a pyramid would continue spending his controlled firms' resources

on lobbying until his total private marginal rate of return equals $\frac{1}{\Delta}$, where $\Delta \equiv \frac{1}{\alpha^{n}}$ is the pyramid 
multiplier defined in equation 3 above.

La Porta et al. (1997) show that countries with weaker political structures have less developed capital markets, and speculate that this might be a deliberate policy to entrench the economic control of wealthy families and politicians. Anecdotal evidence consistent with wealthy families having considerable influence over national governments is also abundant. The Toronto Globe and Mail, Revenue Canada allowed the Bronfman family to move C $\$ 2$ billion to the U.S. in 1991 without triggering capital gains taxes. When the auditor general reported that this "may have circumvented the intent of the tax code", he was attacked by the government finance committee for violating the Bronfmans' right to privacy. ${ }^{35}$ Samuel Gordon, the former chairman of Del Monte Fruit, is reported to have said of the late Ecuadorian billionaire Luis "Lucho" Naboa, "If Lucho wanted a law passed, it passed. He could do things in Ecuador that I, as a multinational, couldn't. ${ }^{36}$ Most famously, Alfred Krupp (1812-1887), heir to the Krupp steel and armaments businesses founded in 1811 by his father Friedrich Krupp, is said to have quipped: "As pants the deer for cooling streams, so do I for regulation."

We can use our cross-country data to explain barriers to entry in local capital markets, both against foreigners obtaining local savings for investment abroad and against locals wanting to use foreign capital. Table 7 investigates whether countries in which inherited family wealth is large relative to GDP show evidence of such barriers, as measured by a set of country-level institutional structure variables.

Based on Feldstein (1994), we use an index of the height of FDI barriers to measure the maintenance of capital market segmentation. We also consider the height of regulatory barriers,

35. See "Auditor was Wrong on Family Trusts" Toronto Globe and Mail September 191996.

36. See "Heirs battle Over Empire in Ecuador" by Jose de Cordoba, Wall Street Journal, September 201995. 
extent of government intervention, and overall tax burden index in each economy as general measures of impediments to market entry and capital flow. These variables are obtained from Holmes, Johnson and Kirkpatrick (1998). They all take high values when the country in question is relatively difficult to enter, and low values when entry is easy. Capital tends to avoid and flee heavy regulation, widespread government intervention and high taxes, and the same policies reduce investment inflows. Barriers against capital outflows therefore often accompany such policies. We also include a measure of the height of trade barriers as a proxy for the general openness of the economy, as capital flow barriers often accompany high trade barriers.

We first estimate simple correlation coefficients of these measures with our country-level ownership structure variables, and then run regressions controlling for per capita GDP. We include the regressions because the country's openness to the world economy may depend on the level of its economic development; but also include the simple correlations because economic growth, and therefore the level of economic development, may be endogenous.

[Table 7 about here]

Columns two through six of Table 7 show that heir billionaire wealth is greater when barriers to FDI are higher, consistent with these economies being subject to barriers to capital inflow. Our other barrier variables are uncorrelated with heir billionaire wealth, except for tax burden, which has a negative sign.

In contrast, entrepreneur billionaire wealth is strongly negatively correlated with FDI barriers height, regulatory barriers height, and extent of government intervention in the economy. Thus, entrepreneur billionaire wealth is high when barriers to capital flow are low, and neither monopsony nor monopoly pricing in capital markets is likely.

Note that the height of general trade barriers in product markets is uncorrelated with heir and 
entrepreneur billionaire wealth. This is consistent with barriers around capital markets being more important than general, overall openness in this context.

In summary, heir control appears to be associated with higher investment flow barriers, but not necessarily with more government regulations, greater tax burdens or trade barriers. In contrast, such barriers are lower in economies with more entrepreneur billionaire wealth.

\section{Diagnosing a Canadian Disease?}

Our query is about why economic growth is negatively related to a country's stock of inherited billionaire wealth and positively related to its self-made billionaire wealth. We propose four underlying explanatory factors. First, billionaire heirs are often entrenched poor managers and have perverse incentives to engage in costly wealth shifting between firms they control. These factors cause heir-controlled firms to perform poorly in the aggregate. Second, extensive old wealth distorts capital markets to favour these entrenched heir-controlled firms. Third, billionaire heircontrolled firms spend less on innovation. Fourth, they also lobby to erect entry barriers.

Our four proposed explanations include both direct and indirect impacts. The direct explanation is that heir billionaires are entrenched poor managers with perverse incentives. The indirect explanations are that heir billionaire wealth distorts capital markets, lowers R\&D, and creates pressure for entry barriers; and that these distortions, in turn, lower economic growth. We have country-level variables that capture the latter two indirect channels: our enterprise R\&D spending and entry barrier variables from Table 7 , and we find cross country evidence consistent with these channels. ${ }^{37}$ If they are the primary channels operating, adding variables that directly

37. It is unclear how we may directly proxy for capital market distortions. Broadly, less distortion might lead to larger markets. But, market capitalization also reflects economic development, which in turn affects growth. Moreover, market capitalization per se does not adequately capture the counter-factual benchmark required; that is, what market capitalization would be if capital market distortions were absent. This benchmark is difficult to obtain - first, because 
capture these effects to the regressions of Table 2 should eliminate the heir and entrepreneur wealth variables. In contrast, if either the direct effect or the capital market distortion channel predominates, adding these same variables should not affect the coefficients or significance of the wealth structure variables.

Table 8 displays regressions of the form

$$
\frac{\Delta Y}{Y}=\beta_{0}+\beta_{1} \ln \left(\frac{Y}{L}\right)+\beta_{2} \frac{I}{K}+\beta_{3} \ln (E)+\mathbf{a} \cdot \mathbf{P}+\mathbf{b} \cdot \mathbf{C}+\varepsilon
$$

where $Y$ is G.D.P., $L$ is population, $I$ is capital investment and $E$ is average years of education. The vector $\mathbf{P}$ contains entry barrier variables and spending on innovation. Different specifications in Table 8 use different subsets of the elements of $\mathbf{P}$. As before, the vector $\mathbf{C}$ contains our countrylevel capital ownership structure variables.

Table 8 shows that extensive regulation, trade barriers, FDI barriers, and high taxes are all correlated with slower economic growth. If we substitute extent of government intervention for extent of regulation, the results are similar, but the intervention variable is uniformly less significant. Surprisingly, and (apparently) inconsistent with the endogenous growth literature, spending on R\&D does not have a significant relationship with economic growth.

[Table 8 about here]

Business entrepreneur billionaire wealth is at best marginally significant in a one-tail test once the height of capital flow barriers is included. This is consistent with entrepreneur billionaires adding to economic growth by lobbying government for economic openness. It is important to note that we cannot assign a direction of causality here: The openness of an economy could be due to

of the endogenous relationship between economic development and market capitalization; and second, because of the incomplete theoretical development of this area. We therefore leave these issues to future research. 
lobbying by entrepreneurs, or openness to world capital markets could allow entrepreneurs to flourish and become billionaires. In either case, it appears that the association of entrepreneur wealth with economic growth is intimately connected to capital market openness and economic freedom in general.

In contrast, heir billionaire wealth remains negatively correlated with economic growth after the barrier to entry variables listed are introduced. This is consistent with the linkage between heir wealth and slow economic growth operating through mechanisms other than barriers to entry and investment in innovation. It is evident from the results in Table 8 that our primary observation of a negative correlation between heir billionaire wealth and economic growth mainly reflects some combination of a direct negative relationship due to heir control and an indirect linkage through capital market distortions. This does not rule out other links, most significantly lobbying for barriers to capital flow.

Poorly performing, heir-controlled firms should be driven out of business in competitive economies. However, preferential access to capital and capital market entry barrier protection may provide heir-controlled firms with an offsetting advantage that allows them to survive. In short, widespread heir billionaire control may lead to a locking in of the status quo, and a permanently reduced rate of economic growth.

Again, a causal interpretation cannot be unambiguously based on cross-section regression results. A reverse causality interpretation of our Table 2 and Table 8 results is that high growth adds to entrepreneur wealth and diminishes heir wealth. If economic growth is typically lower in countries with more entry barriers (Edwards 1998), our results in Table 7 follow. However, this interpretation begs the question: Why should high growth augment entrepreneur wealth but lower heir wealth? Growth through capital accumulation might enrich entrepreneurs, but why should it 
impoverish heirs? Growth through Schumpeterian creative destruction clearly does both, but this answer still leads to the question of why this process operates more rapidly in some economies than in others, which is the focus of this study.

We have argued that widespread inherited corporate control leads to a locking in of the status quo, and a consequently reduced rate of economic growth. We rely heavily on Canadian firm level data to support this argument, so a natural question arises as to its generalization. Are we describing a uniquely Canadian disease? Clearly, the negative cross-country relationship between heir billionaire wealth and economic growth may or may not reflect the same conditions elsewhere. More micro-level studies of other countries would be useful.

\section{Liberalization: The Control and Treatment of the Canadian Disease?}

We have argued that entry barriers and preferential access to capital allow heir control to survive and thus preserve uncompetitive firms. This implies that a sudden and unexpected regime shift that removes many of these advantages should affect heir-controlled firms more adversely than other firms. Moreover, if entrepreneurs have previously been held back by entry barriers and limited access to capital, entrepreneur-controlled firms should be affected more positively by these changes than other firms. Therefore, in this section, we consider an event that suddenly and unexpectedly rendered Canada more open to foreign capital and less protected by entry barriers, the 1988 Canada US Free Trade Agreement (FTA). We conduct an event study using daily stock price data and a comparison of accounting and ownership data before and after the FTA.

The FTA eliminated product market trade barriers over the ten years following ratification according to a pre-set schedule. Chapter 16 of the FTA also provided for prospective national treatment of investors. This immediately barred future capital flow barriers of any kind between 
the two countries, though certain discriminatory taxes and regulations were grandfathered. Chapter 16 unquestionably provoked the greatest outrage from the Canadian nationalist press.

There are several ways the FTA could conceivably have affected the relative standing of heir-controlled firms. First, heightened product market competition could have reduced the values of poorly managed firms. Second, a greater inflow of US capital to Canadian entrepreneurs could reduce heir-controlled firms' market power over the supply capital. It could also create more competition for Canadian corporate assets that are not shielded from takeovers. Third, US firms active in Canada might raise capital there, creating more competition for Canadian savings and eroding entrenched players' market power on that side of the capital market as well. Any or all of these would level the playing field between heirs and others.

The FTA is suitable for an event study because ratification was not expected. Canada had reached final stages in the negotiation of free trade agreements with the United States several times over the previous century, and had always balked at the last minute. To establish a mandate for free trade, the Conservative Prime Minister, Brian Mulroney, had called a snap general election. The protectionist Liberal candidate, John Turner, was far ahead in the polls. Indeed, the best a few late pre-election polls were predicting for the Tories was a draw and a consequent hung parliament or minority government. Neither bade well for the FTA, which required a majority vote for ratification, as the third party in parliament, the socialist New Democrats, was even more protectionist than the Liberals. Nonetheless, to the surprise of virtually everyone, a Conservative majority government was returned with a clear mandate to implement the Free Trade Agreement. ${ }^{38}$ Table 9 lists the major events leading up to the Conservative election victory.

38. The increasing liberalization of the global economy should provide other opportunities for similar tests using data for other countries. 
[Table 9 about here]

\subsection{Stock Price Reactions to the FTA}

We first examine the stock price reactions of firms classified according to types of dominant shareholders, as listed in Table 3. We use the period from November $10^{\text {th }}$ through $21^{\text {st }}$ as our event window. The election was held on Saturday the $19^{\text {th }}$, so the $21^{\text {st }}$ is the first trading day following the Tory victory. November $10^{\text {th }}$ was the day the first polls showing a tie with the Liberals were published, and subsequent polls on the $14^{\text {th }}$ confirmed a tie. These dates thus include the period from the first hint the Liberals might not win through to the news of a Tory majority government.

Our methodology in this section is thus to construct cumulative abnormal returns using daily firm-level stock returns $r_{t}$ as

$$
C A R=\sum_{t=\text { Nov. } 11}^{\text {Nov.21 }}\left(r_{t}-\bar{r}_{i s}\right)
$$

where $\bar{r}_{i, t}$ is the relevant Canadian industry index, constructed using 3 digit SIC codes. We control for industry average stock price movements, rather than market movements, because Thompson (1994, Table 2, pp. 13) finds evidence that industry indexes move on these dates in ways plausibly related to Canada's comparative advantage relative to the US. ${ }^{39}$ We also control for firm age and size. Thus, our regression is as follows

$$
C A R_{i}=\beta_{0}+\beta_{1} \log \left(\text { age }_{i}\right)+\beta_{2} \log \left(\text { sales }_{i}\right)+\beta_{3} \delta_{i}
$$

where the dummy variable $\delta_{i}$ is one or zero according to the type of controlling shareholder, if any, the firm has.

Table 10 shows parameter estimates and significance levels for $\delta_{i}$ when various subsets of

39. Industry bench-marking in a small open economy is problematic, as many large Canadian firms have no similar sized Canadian rivals. Clearly, in this instance, bench-marking with US industry returns makes no sense, so we use Canadian industry averages. We recognize that our industry benchmarks are consequently noisy. 
dominant owners are compared with each other and with widely-held firms.

[Table 10 about here]

Heir-controlled companies appear most adversely affected, while firms controlled by business entrepreneurs appear to gain the most from the unexpected liberalization. ${ }^{40}$ Intriguingly, the stock prices of heir-controlled firms and widely-held firms move in statistically indistinguishable ways. In contrast, stocks of business entrepreneur-controlled firms rise relative to those of widelyheld firms. These findings are consistent with the hypotheses that heir-controlled firms are least able to meet increased product market competition and/or least able to adapt to a more competitive capital market.

\subsection{Changes in Capital Intensity}

As mentioned above, Chapter 16 of the FTA requires national treatment of investors from the US. This encourages US enterprises both to invest in Canada and to raise capital there, raising the general level of competition in Canadian capital markets. Heir-controlled firms should therefore lower their capital intensity as whatever capital market power they formerly enjoyed is eroded.

We return to our statistical analyses of industry-adjusted labor to sales ratios in Table 5 , but now consider the post FTA period from 1992 through 1996. Table 11 also shows the changes in these ratios from the pre-FTA 1984 through 1989 period to this post FTA period for various categories of firms surviving through 1996. Each entry in the first and third panels of Table 11 is

40. Khanna and Palepu (1998) find that economic liberalization in India is associated with a strengthening of family pyramid companies relative to other firms. Interestingly, greater capital market competition is not a part of India's current liberalization strategy. Note, however, that when we drop Canadian pyramid member firms from our comparisons, as in the first and third columns, the significant point estimates move away from zero. Among freestanding firms only, entrepreneur-controlled firms' prices rise more relative to heir-controlled and other firms. This is consistent with intra-group transfers mitigating the positive and negative expected effects of liberalization on group firms. 
a regression coefficient of an ownership dummy for controlling shareholder type in a regression of (US industry adjusted) labor over sales on that dummy and controls for the logarithms of firm age and size. ${ }^{41}$ US industry averages are the industry benchmark in the first panel. US firms the same size and age in the same industry serve in this capacity in the third panel. In the second and fourth panels the dependent variables are the changes for each firm in the figures in the first and third panels respectively from the 1980 s.

[Table 11 about here]

A clear pattern emerges. Table 5 shows that in the 1980 s heir-controlled firms had lower labor intensity than did entrepreneur-controlled firms. Table 11 shows that, for heir-controlled firms that survived, these differences remain in the 1990s, though they have become less significant. Table 5 also shows entrepreneur-controlled firms having insignificantly higher labor intensity than widely-held firms, while heir-controlled firms' labor intensity was significantly lower than that of widely held firms. After liberalization, this changes. Both heir-controlled and entrepreneurcontrolled firms that survived became significantly more labor intensive than widely held firms. The coefficients are also all significantly different from those in the 1980 s period. The second and fourth panel show that surviving heir-controlled and entrepreneur-controlled firms both increased their labor intensity significantly more than widely held firms did. If our assumption that low labor to sales ratio means high capital intensity is valid, widely-held firms began using significantly more capital per worker after liberalization. This is consistent with widely-held firms' access to capital improving.

41. Panel 1 of Table 11 is analogous to Table $4 \mathrm{a}$ in construction, while panel 3 is analogous to Table $4 \mathrm{~b}$. 


\subsection{Stronger Competition?}

The FTA increased product market and capital market competition in Canada. This should have been most detrimental to the least competitive Canadian firms and most advantageous to the best Canadian firms. Tables $12 a$ and $12 b$ repeat the analyses in Tables $4 a$ and $4 b$, and compare firm groups' returns and growth for the 1992 through 1996 period to see if the gaps in performance between firms controlled by different types of shareholders have widened. Heir-controlled firms continue to perform worse than widely-held firms and other firms in general, and the point estimate differences have widened. But the differences between heir-controlled and entrepreneur-controlled firms have narrowed, though entrepreneur-controlled firms continue to grow faster. Entrepreneurcontrolled firms' earnings continue to be lower than those of widely-held firms, and widely-held firms' growth now matches that of entrepreneur-controlled firms.

[Tables $12 \mathrm{a}$ and $12 \mathrm{~b}$ about here]

In short, widely-held firms appear to have benefited disproportionately as Canada became more integrated with US product markets and capital markets. In contrast, heir-controlled firms continue to report slower growth and lower earnings than other firms, and they may actually be falling further behind.

\subsection{The Staying Power of Concentrated Wealth}

The implementation of the free trade agreement between Canada and the U.S. also lets us look at transition rates between different ownership structures as competition grows. To do this, we first compare the ownership structures of our sample of large Canadian firms in 1988, immediately prior to the FTA, to that in 1994, the last year for which we have complete data. ${ }^{42}$ This comparison is

42. Our 1994 ownership data is from the same sources as our 1988 data. 
summarized in the transition matrix of Table 13.

\section{[Table 13 about here]}

The fraction of firms that are either widely-held or owned by a widely-held parent increases from $27.24 \%$ (67 firms) in 1988 to $32.11 \%$ (79 firms) in 1996 . Four out of the eight firms that ceased to be heir-controlled became widely held. Also, most firms whose founders left the scene become widely-held. Of the 27 firms classified as owned by business entrepreneurs, four became widely held, two ended up with a financial institution as a controlling shareholder, one went bankrupt, one was acquired by a foreign parent, and in only one firm was "control" passed on to an heir. In both cases, a $\chi^{2}$ goodness-of-fit test soundly rejects the hypothesis of random changes in ownership structure $(\mathrm{p}$-level $<5 \%) .{ }^{43}$ The proportion of widely-held firms also rose because four of the five privatized state-owned enterprises in our sample of very large firms became widely held. $^{44}$

\subsection{A Cure?}

We contend that the negative relationship between heir control and economic growth is due to heirs often being entrenched poor managers whose firms nonetheless survive due to their preferential access to capital and protection from competition. The liberalization stemming from the Canada U.S. Free Trade Agreement arguably increased both product and capital market

43. In the $\chi^{2}$ tests, we treat categories $i$ (cooperatives) and $j$ (labor-controlled) as one category. We also collapse $c$ (no controlling shareholder) and $f$ (widely-held Canadian parent) into a single category. Because heir-controlled firms cannot become "entrepreneur-controlled" firm, the number of categories into which heir-controlled firms can pass is one minus the number open to entrepreneur-controlled firms. The $\chi^{2}$ statistic is calculated as the sum of squares of observed minus expected transitions over the number of expected transitions. The $\chi^{2}(6)$ statistic for the hypothesis that the transformations of heir-controlled firms follow a random pattern is 27.42 , with a probability value less than $.5 \%$. The $\chi^{2}(7)$ statistics for changes of entrepreneur-controlled firms is 17.99 , with a probability value less then $2.5 \%$.

44. We obtain qualitatively identical result when we include firms without accounting data in the transition matrix reported in Table 13. 
competition in Canada. Heir-controlled firm's inability to compete in this harsher environment is exposed in their negative stock price reactions to the FTA. The value discount outsiders attached to heir control rose. At the same time, heir-controlled firms capital labour ratios converged to those of other firms, suggesting less preferential access to capital. Finally, in the years following the FTA, the firms of departing entrepreneurs tend to become widely-held rather than heir-controlled, again consistent with a large value discount connected with heir control. We suggest, therefore, that liberalization in international trade and capital flow may alleviate the Canadian disease by rendering product and capital markets more competitive, and thereby raising the price families must pay to maintain inherited corporate control.

\section{Conclusions}

The central result of this paper is that the ownership structure of a country's capital matters. Economic growth depends not just on the stock of physical capital, but on who owns it. We find that entrenched family control of a nation's capital is correlated with lower rates of economic growth while entrepreneur billionaire's control of capital is correlated with faster rates of economic growth.

We consider several explanations for this finding. First, old wealth may entrench poor management and control pyramids may distort their incentives. Second, a sharply skewed wealth distribution may create market power in capital markets causing inefficiency. Third, entrenched billionaires have a vested interest in preserving the value of old capital and thus in slowing creative destruction. Fourth, old money becomes entrenched through control of the political system, and most especially by erecting barriers to capital mobility. In contrast, substantial self-made billionaires' wealth is observed where such forces are edentulous and creative destruction occurs. 
Using micro-level data from Canada, we find evidence consistent with the first three explanations. Switching to cross-country data, we find supportive evidence for the third and fourth explanations. In an expanded regression analysis of cross-country differences in growth, we confirm that the positive relationship between entrepreneur-controlled capital and economic growth is connected with lower entry barriers and openness. In contrast, the linkage between heir-controlled capital and lower economic growth is due to not just higher inward foreign investment barriers, but also to entrenched heir control and capital market distortions arising from this.

We dub depressed growth associated with widespread corporate control by wealthy heirs the "Canadian disease". It is characterized by one or more of the following symptoms: poor overall management quality, capital markets and institutions that channel money to large established family firms, a dearth of innovation that locks in the status quo, and political rent-seeking that deters entry. The term "Canadian disease" is appropriate because our empirical evidence relies heavily on Canadian data. We suspect that this malady is widespread globally, and that it is especially deleterious in many developing economies. More work is clearly needed before this supposition can be confirmed.

We show that freer international trade and capital flow appear to level the playing field between heir-controlled, entrepreneur-controlled, and widely-held Canadian firms. If our conjecture that entrenched family control is detrimental to an economy is correct, trade and capital flow liberalization may have beneficial economic effects that are not captured by standard models of international trade and international finance. 


\section{References}

Barro, Robert. 1991. Economic growth in a Cross Section of Countries. Quarterly Journal of Economics 106(424): 407-43.

Barro, Robert and Lee. 1996. International measures of schooling years and schooling quality. American Economic Review, Papers and Proceedings 86 (2): 218-23.

Bebchuk, Lucian, Reinier Kraakman, and George Triantis. 1998. Stock pyramids, cross ownership, dual class equity and leverage: an analysis of alternative arrangements for separating control from cash flow rights. This volume.

Besley, Timothy and Alec Levenson. 1996. The role of inforinal finance in household capital accumulation: evidence from Taiwan. Economic Journal 106(434): 39-59.

Birdsall, Nancy; Ross, David and Sabot, Richard. 1995. Inequality and growth reconsidered: lessons from East Asia. The World Bank Economic Review, 9(3) Sept.

Daniels, Ronald J. and Edward M. Iacobucci. 1998. Some of the causes and consequences of corporate ownership in Canada. This volume.

Daniels, Ronald J. and Randall Morck, eds. 1995. Corporate decision making in Canada. Calgary: Industry Canada and the University of Calgary Press.

Daniels, Ronald J., Randall Morck, and David Stangeland. 1995. In High gear: a case study of the Hees-Edper corporate group. In Corporate decision making in Canada, eds. Ronald J. Daniels and Randall Morck. Calgary: Industry Canada and the University of Calgary Press.

Demsetz, Harold. 1985. The structure of corporate ownership, causes and consequences. Journal of Political Economy 93(6): 1155-77.

Edwards, Sebestian. 1998, "Openness, Productivity and Growth: What do we really know?" Economic Journal, 108 (March), 383-398. 
Feldstein, Martin. 1994. The effects of outbound foreign direct investment on the domestic capital stock. NBER working paper 4668. Cambridge, Mass.: National Bureau of Economic Research.

Feldstein, Martin S. and Charles Horioka. 1980. Domestic saving and international capital flows. Economic Journal 90: 314-29.

Fishlow, Albert. 1996. Inequality, poverty, and growth: Where do we stand?" The World Bank Research Observer: Annual Conference, (Supplement), 25-39.

Gwartney, James and Robert Lawson. 1997. Economic freedom of the world - 1997 Annual Report. The Economic Freedom Network.

Holmes, Kim, Bryan Johnson and Melanie Kirkpatrick. 1997. The 1997 index of economic freedom. Wall Street Journal and the Heritage Foundation, Washington and NewYork.

Hoshi, Takeo, Anil Kashyap and David Scharfstein. 1990. The role of banks in reducing the costs of financial distress in Japan. Journal of Financial Economics 27: 67-88.

Jensen, Michael and William Meckling. 1976. The theory of the firm: managerial behavior, agency costs and ownership structure. Journal of Financial Economics 3: 305-60.

Khanna, Tarun and Krishna Palepu. 1998. Policy shocks, market intermediaries and corporate strategy: the evolution of business groups in Chile and India. Unpublished manuscript. Harvard Business School.

Khanna, Tarun and Krishna Palepu. 1998. The relation between performance and ownership in emerging markets: an empirical analysis of Indian business groups. This volume.

Kim, E. Han, Myeong Kyun Kim, Jay K. Yi. 1998. Economic value-added of non-financial firms listed on the Korea stock exchange. Korea Stock Exchange Publication.

La Porta, Rafael, Florencio Lopez-de-Salinas, Andrei Shleifer and Robert Vishny. 1997. Law and 
finance. Unpublished Manuscript. Harvard University.

La Porta, Rafael, Florencio Lopez-de-Salinas and Andrei Shleifer. 1998. Corporate ownership around the world. Unpublished Manuscript. Harvard University.

La Porta, Rafael, Florencio Lopez-de-Salinas, Andrei Shleifer and Robert Vishny. 1997. Legal determinants of external finance. Journal of Finance 52(3): 1131-50.

Lenway, Stephanie, Randall Morck and Bernard Yeung. 1996. Rent seeking, innovation and protectionism and the American steel industry: an empirical study. Economic Journal 106(435): 410-21.

MacIntosh, Jefferey G. 1994 Legal and institutional barriers to financing innovative enterprises in Canada.. Discussion Paper 94-10. Queen's University School of Policy Studies, Kingston.

Mankiw, N. Gregory. 1995. The growth of nations. Brookings Papers on Economic Activity 1: 275-310.

McConnell, John J. and Henri Servaes. 1990. Additional evidence on equity ownership and corporate value. Journal of Financial Economics 27(2): 595-612.

Murphy, Kevin M., Andrei Shleifer, and Robert W. Vishny. 1991. The allocation of talent: implications for growth. Quarterly Journal of Economics 425:503-530.

Murphy, Kevin M., Andrei Shleifer, and Robert W. Vishny. 1993. Why is rent-seeking costly to growth? American Economic Review 82(2): 409-14.

Nickell, Stephen J. 1996. Competition and corporate performance. Journal of Political Economy 104(4): 724-46.

Shleifer, Andrei and Robert Vishny. 1986. Large shareholders and corporate control. Journal of Political Economy 95: 461-88. 
Shleifer, Andrei and Robert Vishny. 1989. Management Entrenchment: The Case of Manager-Specific Investments. Journal of Financial Economics Nov 1989, v25n1, p. 123-139.

Stulz, René. 1988. On takeover resistance, managerial discretion and shareholder wealth. Journal of Financial Economics 20(1/2).

Thompson, Aileen J. 1994. Trade liberalization, comparative advantage, and scale economies: stock market evidence from Canada. Journal of International Economics 37: 1-27.

Wolfenzohn, Daniel. 1998. A theory of pyramidal ownership. Unpublished manuscript. Harvard University. 
Billionaires and Billionaire Wealth by Country and by Source of Wealth

\begin{tabular}{|c|c|c|c|c|c|c|c|}
\hline \multirow[b]{2}{*}{ Country } & \multirow[b]{2}{*}{$\begin{array}{c}\text { Billionaires } \\
\text { per million } \\
\text { People }\end{array}$} & \multicolumn{6}{|c|}{ Billions in Wealth over Billions of GDP } \\
\hline & & $\begin{array}{c}\text { Total } \\
\text { Billionaire } \\
\text { Wealth }\end{array}$ & $\begin{array}{c}\text { Entrepreneur } \\
\text { Billionaire } \\
\text { Wealth }\end{array}$ & $\begin{array}{c}\text { Heir } \\
\text { Billionaire } \\
\text { Wealth }\end{array}$ & $\begin{array}{c}\text { Probable } \\
\text { Heir } \\
\text { Billionaire } \\
\text { Wealth } \\
\end{array}$ & $\begin{array}{l}\text { Entrepreneur } \\
\& \text { Heir Control }\end{array}$ & $\begin{array}{c}\text { Political } \\
\text { Family } \\
\text { Billionaire } \\
\text { Wealth }\end{array}$ \\
\hline Argentina & .118 & 26.378 & 0 & 26.378 & 0 & 0 & 0 \\
\hline Australia & .056 & 7.718 & 7.718 & 0 & 0 & 0 & 0 \\
\hline Austria & 0 & 0 & 0 & 0 & 0 & 0 & 0 \\
\hline Belgium & 0 & 0 & 0 & 0 & 0 & 0 & 0 \\
\hline Brazil & .038 & 22.852 & 12.431 & 4.936 & 0 & 5.4845 & 0 \\
\hline Canada & .173 & 40.204 & 0 & 24.898 & 15.3061 & 0 & 0 \\
\hline Chile & .218 & 102.174 & 36.957 & 34.783 & 0 & 30.4348 & 0 \\
\hline Columbia & .086 & 39.286 & 0 & 0 & 39.2857 & 0 & 0 \\
\hline Denmark & .193 & 17.293 & 0 & 0 & 0 & 17.2932 & 0 \\
\hline Ecuador & 0 & 0 & 0 & 0 & 0 & 0 & 0 \\
\hline Finland & 0 & 0 & 0 & 0 & 0 & 0 & 0 \\
\hline France & .191 & 16.799 & 2.07 & 11.863 & 2.8662 & 0 & 0 \\
\hline Germany & .504 & 54.648 & 6.523 & 39.856 & 8.2691 & 0 & 0 \\
\hline Greece & .48 & 133.333 & 0 & 66.667 & 66.6667 & 0 & 0 \\
\hline Hong Kong & 2.188 & 361.307 & 193.157 & 157.802 & 10.3477 & 0 & 0 \\
\hline Iceland & 0 & 0 & 0 & 0 & 0 & 0 & 0 \\
\hline India & .002 & 11.985 & 0 & 8.24 & 3.7453 & 0 & 0 \\
\hline Indonesia & .02 & 160.598 & 35.948 & 11.765 & 17.6471 & 0 & 95.238 \\
\hline Ireland & 0 & 0 & 0 & 0 & 0 & 0 & 0 \\
\hline Israel & .395 & 41.429 & 41.429 & 0 & 0 & 0 & 0 \\
\hline Italy & .088 & 10.352 & 4.658 & 5.694 & 0 & 0 & 0 \\
\hline Japan & .289 & 18.252 & 5.5 & 7.895 & 4.857 & 0 & 0 \\
\hline Korea & .068 & 31.988 & 12.422 & 19.565 & 0 & 0 & 0 \\
\hline Malaysia & .213 & 125 & 70 & 0 & 55 & 0 & 0 \\
\hline Mexico & .267 & 128.198 & 15.988 & 2.349 & 60.4651 & 31.3953 & 0 \\
\hline Netherlands & .196 & 36.739 & 0 & 18.73 & 0 & 3.8095 & 14.199 \\
\hline Norway & 0 & 0 & 0 & 0 & 0 & 0 & 0 \\
\hline Peru & 0 & 0 & 0 & 0 & 0 & 0 & 0 \\
\hline Philippines & .072 & 100 & 17.742 & 37.097 & 27.4194 & 17.7419 & 0 \\
\hline Portugal & 0 & 0 & 0 & 0 & 0 & 0 & 0 \\
\hline Singapore & .935 & 85.957 & 28.068 & 22.805 & 35.0846 & 0 & 0 \\
\hline South Africa & .025 & 13.158 & 13.158 & 0 & 0 & 0 & 0 \\
\hline Spain & .077 & 8.932 & 0 & 5.664 & 3.268 & 0 & 0 \\
\hline Sweden & .229 & 56.354 & 0 & 0 & 6.6298 & 49.7238 & 0 \\
\hline Switzerland & 1.133 & 76.953 & 9.375 & 47.656 & 7.4219 & 12.5 & 0 \\
\hline Taiwan & .287 & 72.603 & 48.858 & 0 & 9.589 & 14.1553 & 0 \\
\hline Thailand & .105 & 122.832 & 12.5 & 26.563 & 41.4063 & 29.6875 & 12.676 \\
\hline Turkey & .034 & 28.358 & 0 & 0 & 0 & 28.3582 & 0 \\
\hline United Kingdom & .086 & 11.166 & 1.134 & 7.423 & 0 & 2.268 & .341 \\
\hline United States & .465 & 39.52 & 9.34 & 14.7 & 12.51 & 2.98 & 0 \\
\hline Venezuela & .097 & 43.103 & 0 & 43.103 & 0 & 0 & 0 \\
\hline
\end{tabular}

Sources: Forbes 1,000 lists of the world's richest people, 1993. 
Table 2 The Cross-Country Relationship Between Economic Growth and Capital Ownership Structure Controlling for Current per Capita Income, Capital Investment Rate, and Level of Education

\begin{tabular}{|c|c|c|c|c|c|c|c|c|}
\hline & 2.1 & 2.2 & 2.3 & 2.4 & 2.5 & 2.6 & 2.7 & 2.8 \\
\hline Intercept & $\begin{array}{l}1.43 \\
(. .32)\end{array}$ & $\begin{array}{l}1.58 \\
(.30)\end{array}$ & $\begin{array}{l}1.59 \\
(.27)\end{array}$ & $\begin{array}{l}1.65 \\
(.28)\end{array}$ & $\begin{array}{l}1.75 \\
(.22)\end{array}$ & $\begin{array}{l}1.73 \\
(.26)\end{array}$ & $\begin{array}{l}1.86 \\
(.20)\end{array}$ & $\begin{array}{l}1.78 \\
(.25)\end{array}$ \\
\hline $\begin{array}{l}\text { Log of per capita } \\
\text { GDP: } \ln (Y / L)\end{array}$ & $\begin{array}{l}-1.76 \\
(.00)\end{array}$ & $\begin{array}{r}-1.77 \\
(.00)\end{array}$ & $\begin{array}{r}-1.80 \\
(.00)\end{array}$ & $\begin{array}{r}-1.79 \\
(.00)\end{array}$ & $\begin{array}{l}-1.54 \\
(.00)\end{array}$ & $\begin{array}{r}-1.66 \\
(.00)\end{array}$ & $\begin{array}{r}-1.62 \\
(.00)\end{array}$ & $\begin{array}{r}-1.69 \\
(.00)\end{array}$ \\
\hline $\begin{array}{r}\text { Capital Accumulation } \\
\text { Rate: } I / K\end{array}$ & $\begin{array}{l}.210 \\
(.00)\end{array}$ & $\begin{array}{l}.216 \\
(.00)\end{array}$ & $\begin{array}{l}.208 \\
(.00)\end{array}$ & $\begin{array}{l}.214 \\
(.00)\end{array}$ & $\begin{array}{l}.173 \\
(.00)\end{array}$ & $\begin{array}{l}.199 \\
(.00)\end{array}$ & $\begin{array}{l}.178 \\
(.00)\end{array}$ & $\begin{array}{l}.199 \\
(.00)\end{array}$ \\
\hline $\begin{array}{l}\text { Average Total Years } \\
\text { of Education: } \ln (E)\end{array}$ & $\begin{array}{l}.238 \\
(.27)\end{array}$ & $\begin{array}{l}.203 \\
(.35)\end{array}$ & $\begin{array}{l}.253 \\
(.23)\end{array}$ & $\begin{array}{l}.214 \\
(.32)\end{array}$ & $\begin{array}{l}.242 \\
(.24)\end{array}$ & $\begin{array}{l}.200 \\
(.35)\end{array}$ & $\begin{array}{l}.259 \\
(.21)\end{array}$ & $\begin{array}{l}.213 \\
(.32)\end{array}$ \\
\hline $\begin{array}{r}\text { Business Entrepreneur } \\
\text { Billionaire Wealth Over } \\
\text { GDP: } B / Y\end{array}$ & $\begin{array}{l}.440 \\
(.00)\end{array}$ & $\begin{array}{l}.37 \\
(.00)\end{array}$ & $\begin{array}{l}.42 \\
(.00)\end{array}$ & $\begin{array}{l}.37 \\
(.00)\end{array}$ & $\begin{array}{l}.495 \\
(.00)\end{array}$ & $\begin{array}{l}.382 \\
(.00)\end{array}$ & $\begin{array}{l}.45 \\
(.00)\end{array}$ & $\begin{array}{l}.37 \\
(.00)\end{array}$ \\
\hline $\begin{array}{r}\text { Heir Billionaire Wealth } \\
\text { Over GDP: } H / Y\end{array}$ & $\begin{array}{r}-.292 \\
(.03)\end{array}$ & $\begin{array}{l}-.168 \\
(.10)\end{array}$ & $\begin{array}{l}-.268 \\
(.03)\end{array}$ & $\begin{array}{l}-.157 \\
(.09)\end{array}$ & $\begin{array}{r}-.407 \\
(.01)\end{array}$ & $\begin{array}{r}-.191 \\
(.09)\end{array}$ & $\begin{array}{l}-.33 \\
(.01)\end{array}$ & $\begin{array}{l}-.17 \\
(.08)\end{array}$ \\
\hline $\begin{array}{r}\text { Definition of "Heir"" } \\
\text { R squared }\end{array}$ & $\begin{array}{c}H_{1} \\
0.519\end{array}$ & $\begin{array}{c}\mathrm{H}_{2} \\
0.488 \\
\end{array}$ & $\begin{array}{c}H_{3} \\
0.531\end{array}$ & $\begin{array}{c}H_{4} \\
0.489\end{array}$ & $\begin{array}{c}H_{5} \\
0.545\end{array}$ & $\begin{array}{c}H_{6} \\
0.491\end{array}$ & $\begin{array}{c}H_{7} \\
0.536 \\
\end{array}$ & $\begin{array}{c}H_{3} \\
0.491 \\
\end{array}$ \\
\hline
\end{tabular}

Note: Numbers in parenthesis are two tailed t-test probability levels for rejecting a zero coefficient. Coefficients in boldface are statistically significant at $90 \%$ confidence or more. Sample of 39 countries consists of the countries listed in Table 1 minus the U.K. and U.S.

' $H_{l}$ includes only the wealth of billionaires known positively to be heirs, politicians or politicians' relations. $H_{2}$ also includes the wealth of billionaires who are probably heirs. $H_{3}$ includes $H_{1}$ plus fortunes jointly controlled by a founder and his heirs. $H_{4}$ includes all the above. $H_{5}$ through $H_{8}$ are analogous to $H, H_{2}, H_{3}$ and $H_{4}$ but do not include politician billionaires and their relations. 
Table 3 Publicly Traded Firms Among the Largest 500 Canadian Firms by Sales, by Type of Controlling Shareholder

\begin{tabular}{|c|c|c|c|}
\hline Type of Controlling Shareholder ${ }^{a}$ & Firms ${ }^{b}$ & $\begin{array}{c}\text { Average } \\
\text { Sales }^{\mathrm{c}}\end{array}$ & $\begin{array}{c}\text { Fraction } \\
\text { of Total } \\
\text { Sales } \\
\end{array}$ \\
\hline a. Heir, direct or via pyramid & 44 & 1.15 & 0.20 \\
\hline b. Business entrepreneur, direct or via pyramid & 27 & 0.42 & 0.05 \\
\hline c. No controlling shareholder & 53 & 1.37 & 0.29 \\
\hline e. Controlled by widely held Canadian parent, direct or via pyramid & 14 & 1.03 & 0.06 \\
\hline d. Others individual or family, type unclear & 29 & 0.32 & 0.04 \\
\hline e. Financial institution or investment fund & 6 & 0.46 & 0.01 \\
\hline f. Foreign parent firm, direct or via pyramid & 49 & 1.34 & 0.26 \\
\hline g. government & 23 & 1.02 & 0.09 \\
\hline h. Worker ownership & 1 & 0.16 & 0.00 \\
\hline Total & $246^{\mathrm{d}}$ & 1.02 & 1.00 \\
\hline
\end{tabular}

Note: Sample is firms in the 1988 Financial Post 500 for which accounting and ownership data are available.

A controlling shareholder, under Canadian law, is anyone who controls more than $20 \%$ voting powers. Where there is more than one controlling shareholder, the firm is classified according to the type of the largest shareholder.

${ }^{\circ} \mathrm{Canadian}$ reporting requirements allow consolidated financial reports for corporate groups. Consequently the number of firms is understated.

'The number of firms and average sales are for those firms with reported sales in 1988 and accounting data for the variables used in Table 4. (Firms not reporting firm age are included.) Sales are for 1988 and are in billions of US dollars.

${ }^{d}$ Of the 500 largest firms, 254 are privately held so no details of the ownership structure are available. 


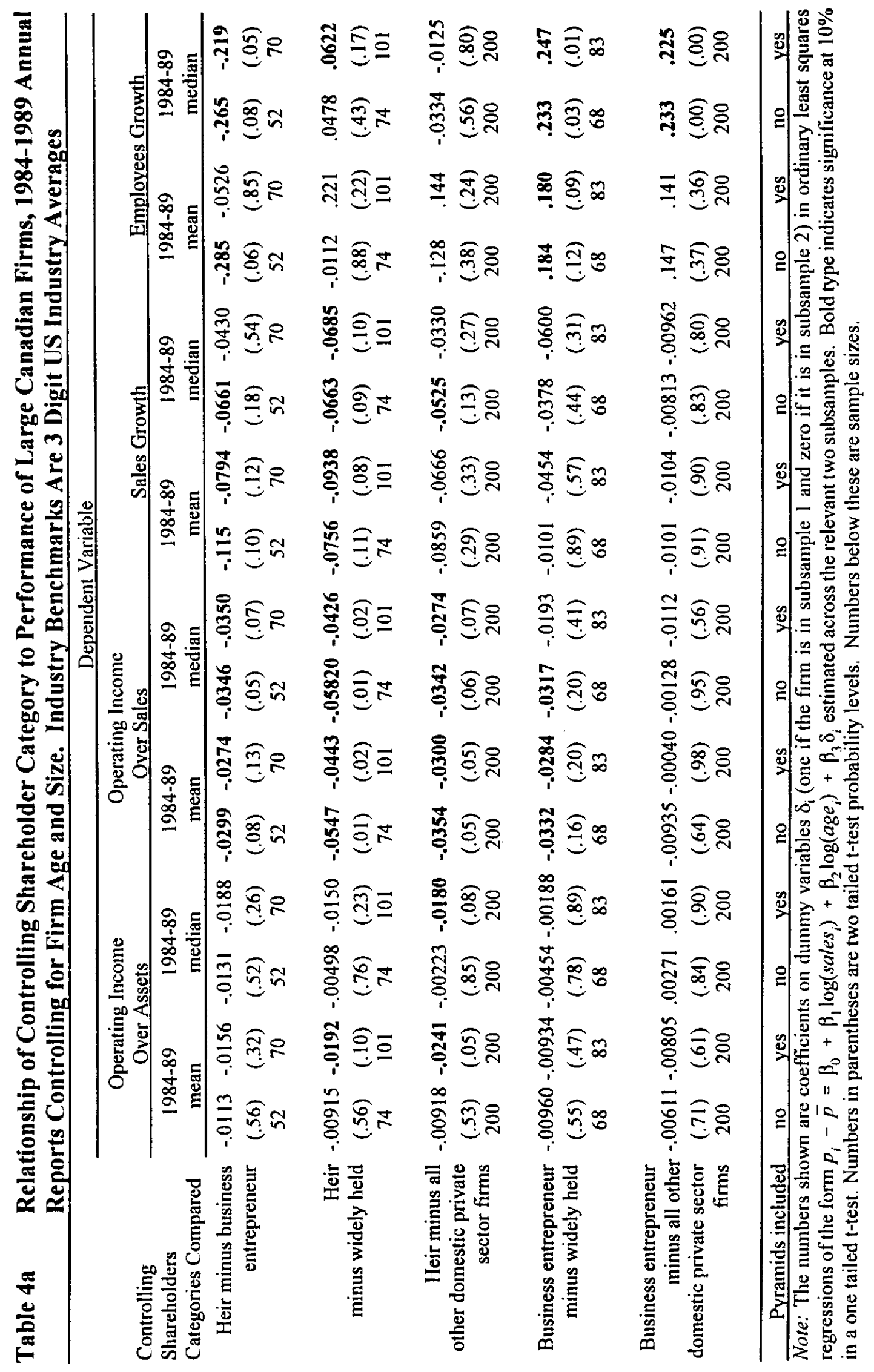




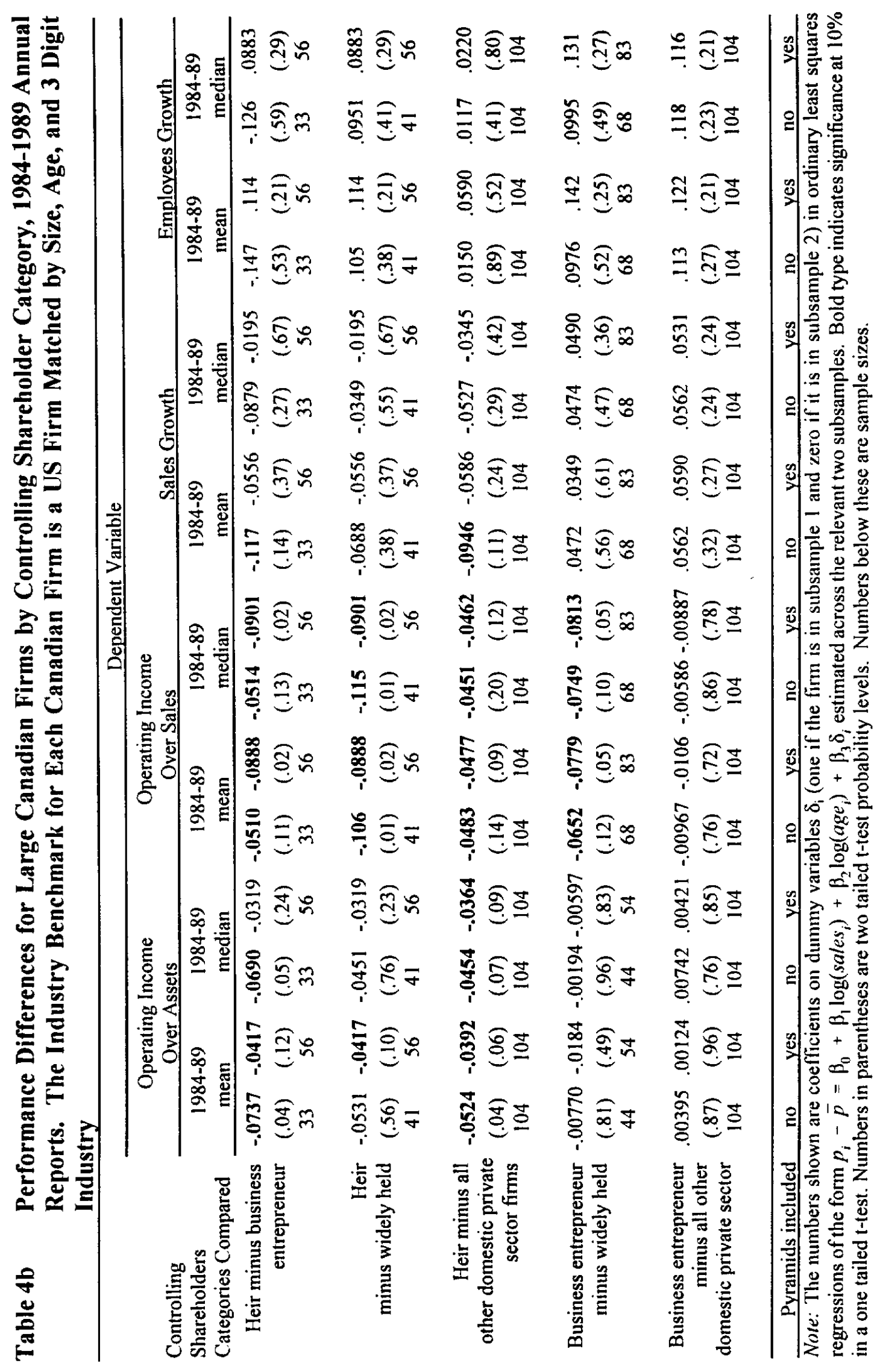




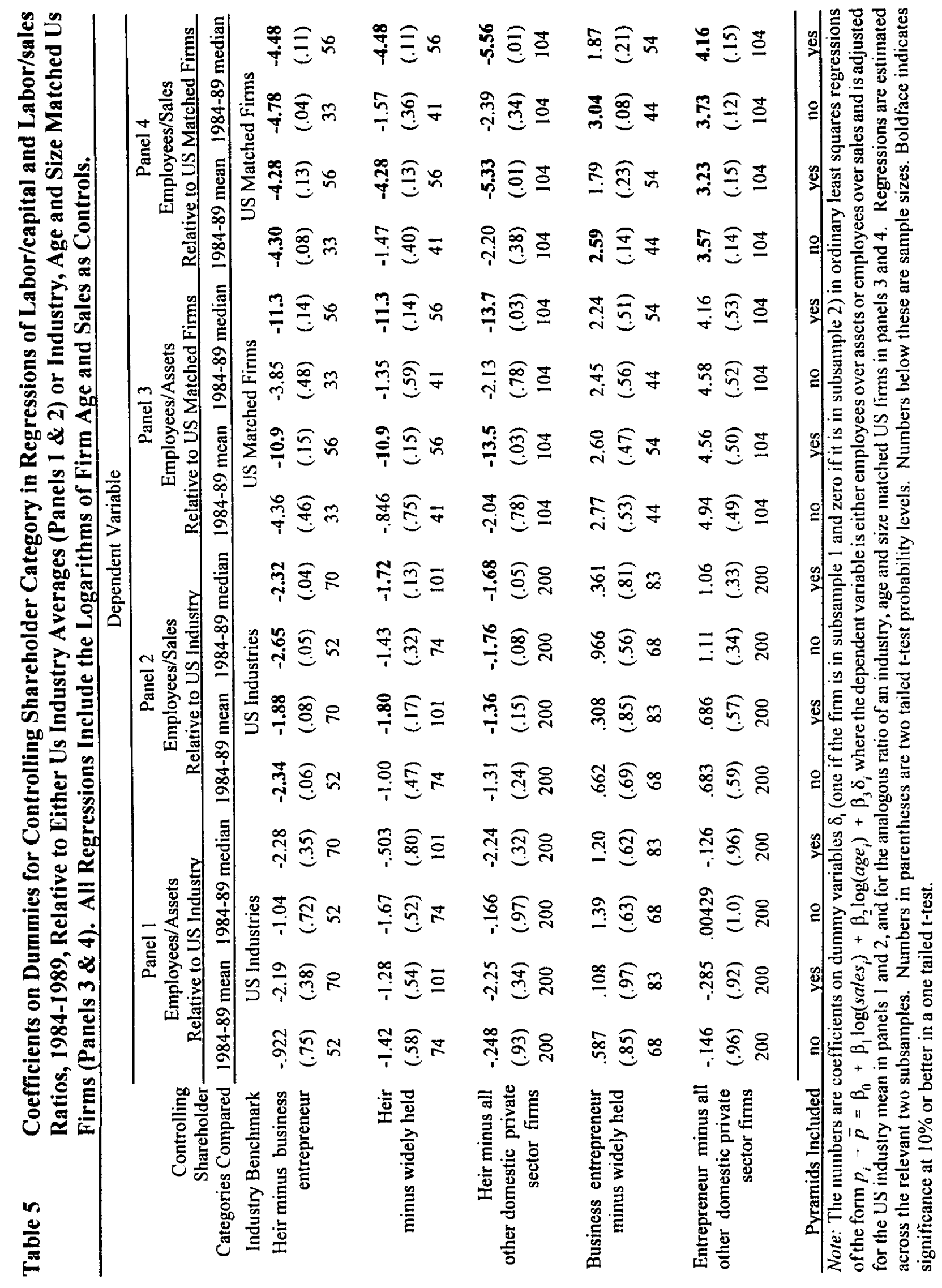


Table 6 Research and Development Activity for Large Canadian Firms, by Controlling Shareholder Category

\begin{tabular}{|c|c|c|c|c|}
\hline \multirow[b]{2}{*}{$\begin{array}{l}\text { Controlling Shareholder } \\
\text { Categories Compared }\end{array}$} & \multicolumn{4}{|c|}{ Dependent Variable } \\
\hline & $\begin{array}{c}\text { Reported } \\
\text { R\&D }>0 \text { dummy" } \\
\end{array}$ & $\begin{array}{c}\text { Reported } \\
\text { R\&D/Sales } \\
\text { 1984-89 mean }\end{array}$ & $\begin{array}{c}\text { Relative } \\
\text { Reported } \\
\text { R\&D dummy } \\
\end{array}$ & $\begin{array}{c}\text { Relative Reported } \\
\text { R\&D/Sales } \\
1984-89 \text { mean }^{c} \\
\end{array}$ \\
\hline & 6.1 & 6.2 & 6.2 & 6.4 \\
\hline $\begin{array}{r}\text { Estimation technique } \\
\text { Industry benchmarks } \\
\text { Controls for } \\
\end{array}$ & $\begin{array}{c}\text { logit } \\
\text { none } \\
\text { size and age } \\
\end{array}$ & $\begin{array}{c}\text { tobit } \\
\text { none } \\
\text { size and age } \\
\end{array}$ & $\begin{array}{l}\text { ordered logit } \\
\text { US matches } \\
\text { size and age }\end{array}$ & $\begin{array}{c}\text { O.L.S. } \\
\text { US matches } \\
\text { size and age }\end{array}$ \\
\hline $\begin{array}{r}\text { Heirs minus } \\
\text { business entrepreneur }\end{array}$ & $\begin{array}{l}-1.16 \\
(.19)\end{array}$ & $\begin{array}{c}-.0114 \\
(.24)\end{array}$ & $\begin{array}{l}.665 \\
(.34)\end{array}$ & $\begin{array}{c}-.000708 \\
(.78)\end{array}$ \\
\hline & 70 & 70 & 42 & 42 \\
\hline Heirs minus widely held & $\begin{array}{l}-1.43 \\
(.03)\end{array}$ & $\begin{array}{c}-.0469 \\
(.03)\end{array}$ & $\begin{array}{l}-1.34 \\
(.06)\end{array}$ & $\begin{array}{l}-.00115 \\
(.73)\end{array}$ \\
\hline & 101 & 101 & 56 & 56 \\
\hline $\begin{array}{l}\text { Heirs minus all other } \\
\text { domestic private sector }\end{array}$ & $\begin{array}{c}-1.518 \\
(.02) \\
200\end{array}$ & $\begin{array}{c}-.0451 \\
(.01) \\
200\end{array}$ & $\begin{array}{c}-.704 \\
(.17) \\
104\end{array}$ & $\begin{array}{c}-.00104 \\
(.71) \\
104\end{array}$ \\
\hline $\begin{array}{l}\text { Business entrepreneur } \\
\text { minus widely held }\end{array}$ & $\begin{array}{c}-.246 \\
(.71) \\
83\end{array}$ & $\begin{array}{c}-.0175 \\
(.38) \\
83\end{array}$ & $\begin{array}{c}-.743 \\
(.33) \\
54\end{array}$ & $\begin{array}{c}.00106 \\
(.79) \\
54\end{array}$ \\
\hline $\begin{array}{r}\text { Founders minus all other } \\
\text { non-government }\end{array}$ & $\begin{array}{c}-.218 \\
(.71) \\
200\end{array}$ & $\begin{array}{c}-.0145 \\
(.42) \\
200\end{array}$ & $\begin{array}{l}.183 \\
(.75) \\
104\end{array}$ & $\begin{array}{c}.00126 \\
(.67) \\
104\end{array}$ \\
\hline
\end{tabular}

Note: Table entries are coefficients on dummy variables $\mathrm{d}_{i}$ (one if the firm is in subsample 1 and zero if it is in subsample 2). Regressions 6.1 and 6.2 are of the form $y_{i}=\beta_{0}+\beta_{1} \log \left(\right.$ sales $\left._{i}\right)+\beta_{2} \log ($ age $)+\beta_{3} d_{i}$ while subsequent columns are of the form $y_{i}-\bar{y}_{i}=\beta_{0}+\beta_{1} \log \left(\right.$ sales $\left._{i}\right)+\beta_{2} \log \left(\right.$ age $\left.e_{i}\right)+\beta_{3} d_{i}$ where $\bar{y}_{i}$ is the value of $y$ for the matching US firm. Numbers in parentheses are two-tailed t-test probability levels and numbers below them are sample sizes.

Dummy is one for R\&D > 0 , zero otherwise.

b Dummy is 2 if the Canadian firm reports R\&D but its US match does not, 1 if both either do or do not report R\&D and 0 if the Canadian firm reports no R\&D but its US match does.

'Dependent variable is the Canadian firm's R\&D over sales minus that of its US match. 

investment and Capital Ownership Structure

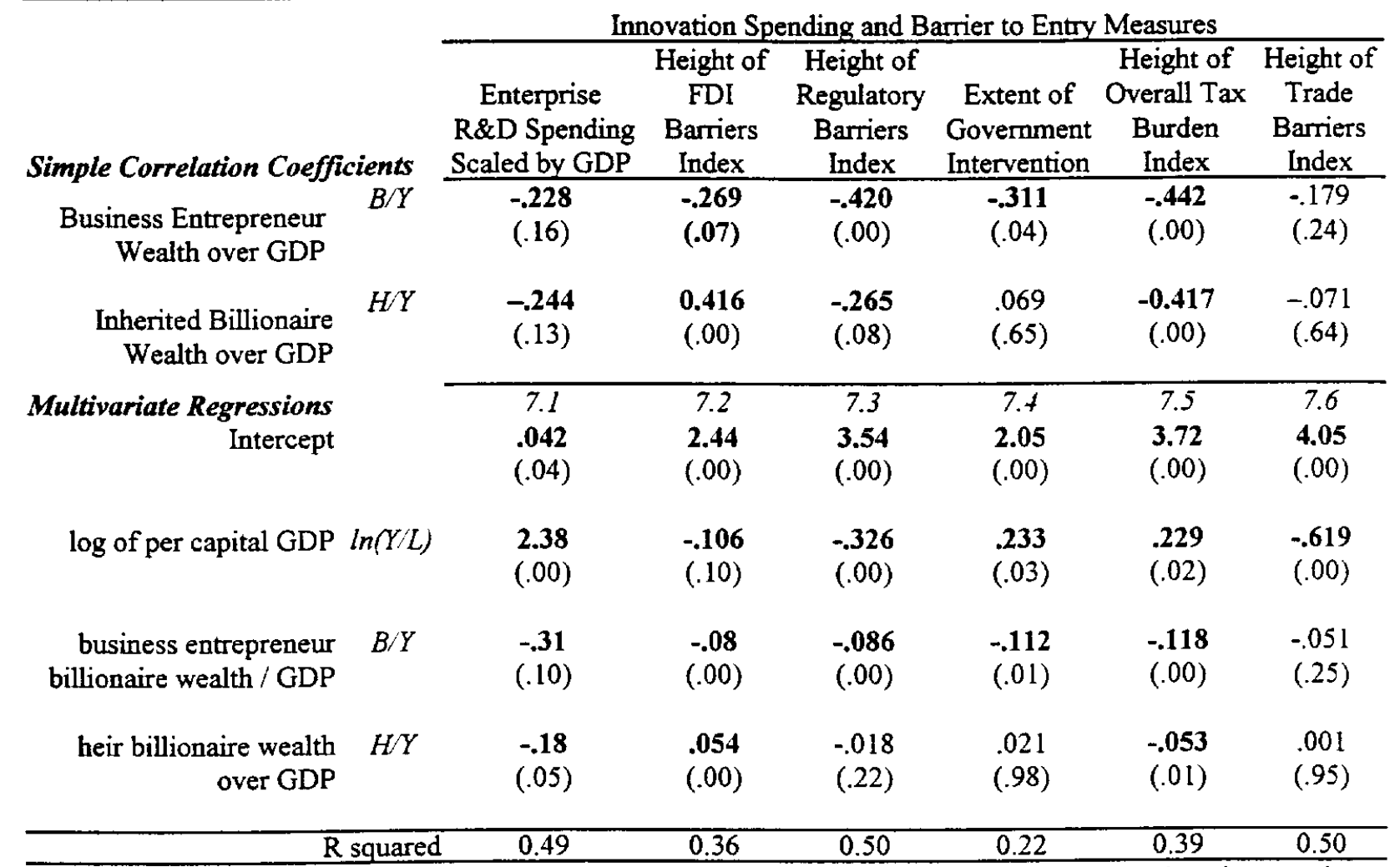

Note: The maximal sample consists of the countries listed in Table 1 minus the US and UK. Numbers in parentheses are probability levels for two tailed $t$ tests. 
Table 8 The Cross-country Relationship Between Economic Growth and Capital Ownership Structure Controlling for Current per Capita Income, Capital Investment Rate, Level of Education, Enterprise R\&D Investment, and Various Measures Barriers to Entry

\begin{tabular}{|c|c|c|c|c|}
\hline & 8.1 & 8.2 & 8.3 & 8.4 \\
\hline Intercept & 7.39 & 2.72 & 7.88 & 4.99 \\
\hline & $(.05)$ & $(.58)$ & $(.02)$ & $(.39)$ \\
\hline Log of per capita GDP & -2.30 & -2.28 & -2.36 & -2.40 \\
\hline $\ln (Y / L)$ & $(.00)$ & $(.00)$ & $(.00)$ & $(.00)$ \\
\hline Capital accumulation rate & .197 & .154 & .241 & .188 \\
\hline$I / K$ & $(.00)$ & $(.02)$ & $(.00)$ & $(.02)$ \\
\hline Average total years of education & .312 & .503 & .323 & .444 \\
\hline$E$ & $(.14)$ & $(.05)$ & $(.12)$ & $(.09)$ \\
\hline \multirow[t]{2}{*}{ Extensive business regulations } & -1.00 & -.503 & -1.058 & -.757 \\
\hline & $(.08)$ & $(.47)$ & $(.05)$ & $(.34)$ \\
\hline \multirow[t]{2}{*}{ Height of trade barriers } & -.428 & -.154 & - & - \\
\hline & $(.27)$ & $(.74)$ & & \\
\hline Height of FDI barriers & - & - & -1.055 & -.694 \\
\hline & & & $(.05)$ & $(.44)$ \\
\hline \multirow{4}{*}{$\begin{array}{l}\text { Enterprise R\&D spending over GDP } \\
\qquad R \& D / Y\end{array}$} & - & -.039 & $\cdot$ & -.013 \\
\hline & & $(.69)$ & & $(.90)$ \\
\hline & -.242 & .283 & -.255 & .144 \\
\hline & $(.59)$ & $(.64)$ & $(.56)$ & $(.81)$ \\
\hline \multirow{3}{*}{$\begin{array}{r}\text { Business entrepreneur billionaire wealth } \\
\text { over GDP } \\
B / Y\end{array}$} & .29 & .389 & .23 & .32 \\
\hline & $(.07)$ & $(.03)$ & (.14) & $(.12)$ \\
\hline & & & & \\
\hline Heir billionaire wealth over GDP &.- .30 & -.28 & -.27 & -.263 \\
\hline$H / Y$ & $(.03)$ & $(.07)$ & $(.04)$ & $(.07)$ \\
\hline $\mathrm{R}$ squared & 0.579 & 0.578 & 0.603 & 0.587 \\
\hline
\end{tabular}

Note: The sample consists of the countries listed in Table 1 minus the U.S. and U.K. When we include Enterprise R\&D spending (scaled by GDP, 1993 data from OECD, 1996, Industrial Competitiveness Benchmarking Business Environments in the Global Economy) we lose 5 countries due to missing data, they are Austria, Belgium, Taiwan, South Africa, and Singapore. 
Table 9 Sequence of Events Leading Up to the Canada U.S. Free Trade Agreement Ratification by the Canadian Parliament

\begin{tabular}{|c|c|c|c|}
\hline $\begin{array}{l}\text { Event } \\
\text { Date }\end{array}$ & $\begin{array}{c}\text { First } \\
\text { Trading Date }\end{array}$ & Event & $\begin{array}{c}\text { Impact on } \\
\text { Entrenched Firms }\end{array}$ \\
\hline & & General Background & \\
\hline & & $\begin{array}{l}\text { Canada has negotiated free trade with the US } \\
\text { several times over the past century, but never } \\
\text { ratified the result. }\end{array}$ & positive? \\
\hline & & Threat to deny fast track authorization & \\
\hline $04 / 11 / 86$ & $14 / 4 / 86$ & $\begin{array}{l}\text { The US Senate Finance committee threatened to } \\
\text { deny fast-track consideration of the FTA. } \\
\text { Approval of fast track procedure }\end{array}$ & positive? \\
\hline $23 / 4 / 86$ & $24 / 4 / 86$ & $\begin{array}{l}\text { The Senate finance committee vote was tied, } \\
\text { negotiations could begin. }\end{array}$ & negative? \\
\hline $23 / 9 / 87$ & $24 / 9 / 87$ & $\begin{array}{l}\text { Negotiations were discontinued } \\
\text { Negotiations were discontinued. }\end{array}$ & positive? \\
\hline & & Negotiations Might Restart & \\
\hline $30 / 9 / 87$ & $1 / 10 / 87$ & $\begin{array}{l}\text { Discussions of the possibility of resuming } \\
\text { negotiations announced at midnight, Sept. } 30 \text {. }\end{array}$ & negative? \\
\hline $2 / 10 / 87$ & $2 / 10 / 87$ & $\begin{array}{l}\text { Negotiations Resume } \\
\text { Agreement reached }\end{array}$ & negative? \\
\hline $3 / 10 / 87$ & $5 / 10 / 87$ & $\begin{array}{l}\text { A trade accord was reached. For the first time, } \\
\text { the media treats the possibility of free trade with } \\
\text { the United States as a serious possibility. } \\
\text { Turner Does Well in Televised Pre-Election Debate }\end{array}$ & negative \\
\hline $26 / 10 / 88$ & $26 / 10 / 88$ & $\begin{array}{l}\text { Liberal opposition leader John Turner vows on } \\
\text { national television to dismantle the FTA. }\end{array}$ & positive \\
\hline $28 / 10 / 88$ & $28 / 10 / 88$ & $\begin{array}{c}\text { Turner Declared Clear Winner of Televised Debate } \\
\text { Globe-Environomics poll result released. }\end{array}$ & positive \\
\hline $7 / 11 / 88$ & $7 / 11 / 88$ & $\begin{array}{l}\text { Liberal Party } 10 \% \text { Ahead } \\
\text { Gallup Poll results. } \\
\text { Tories and Liberals Tied }\end{array}$ & positive \\
\hline $10 / 11 / 88$ & $10 / 11 / 88$ & $\begin{array}{l}\text { Globe-Environomics Poll. A minority } \\
\text { government or hung parliament might not be able } \\
\text { to ratify the FTA }\end{array}$ & negative? \\
\hline $14 / 11 / 88$ & $14 / 11 / 88$ & $\begin{array}{l}\text { Tories and Liberals Tied } \\
\text { Gallup Poll confirms the } 10 \text { Nov. Globe- } \\
\text { Environomics Poll result. } \\
\text { Surprise Tory Majority Government }\end{array}$ & negative? \\
\hline $19 / 11 / 88$ & $21 / 11 / 88$ & $\begin{array}{l}\text { Prime Minister Mulroney's Tories win a } 2^{\text {nd }} \text { term } \\
\text { with a surprise majority }\end{array}$ & negative \\
\hline
\end{tabular}




\section{Table 10 Cumulative Abnormal Returns of Large Canadian Firms Upon the News that the Canada-US Free Trade Would Be Ratified by the Canadian Parliament}

\begin{tabular}{|c|c|c|c|c|}
\hline $\begin{array}{c}\text { Controlling Shareholder } \\
\text { Categories Compared }\end{array}$ & \multicolumn{2}{|c|}{ Mean Differences } & \multicolumn{2}{|c|}{$\begin{array}{l}\text { Mean Residual Differences } \\
\text { controlling for firm age \& size }\end{array}$} \\
\hline \multirow{3}{*}{$\begin{array}{c}\text { heirs minus } \\
\text { business entrepreneurs }\end{array}$} & -.0993 & -0.0729 & -.0765 & -0.0623 \\
\hline & $(.03)$ & $(.04)$ & $(.12)$ & $(.10)$ \\
\hline & 15 & 23 & 15 & 23 \\
\hline \multirow{3}{*}{$\begin{array}{l}\text { heirs minus } \\
\text { widely held }\end{array}$} & .01347 & .0260 & .00034 & .0188 \\
\hline & $(.37)$ & $(.26)$ & $(.50)$ & $(.33)$ \\
\hline & 24 & 37 & 24 & 37 \\
\hline \multirow{3}{*}{$\begin{array}{l}\text { heirs minus } \\
\text { all other private sector firms }\end{array}$} & -.0317 & -.0068 & -.0316 & -.0098 \\
\hline & $(.22)$ & $(.42)$ & $(.23)$ & $(.39)$ \\
\hline & 61 & 61 & 61 & 61 \\
\hline \multirow{3}{*}{$\begin{array}{l}\text { business entrepreneurs minus } \\
\text { widely held }\end{array}$} & .1128 & .0989 & .1328 & .1271 \\
\hline & $(.00)$ & $(0.04)$ & $(.00)$ & $(.02)$ \\
\hline & 21 & 28 & 21 & 28 \\
\hline \multirow{3}{*}{$\begin{array}{l}\text { business entrepreneurs minus } \\
\text { all other private sector }\end{array}$} & .0802 & .0767 & .0916 & .0857 \\
\hline & $(.05)$ & $(.05)$ & $(.04)$ & $(0.04)$ \\
\hline & 61 & 61 & 61 & 61 \\
\hline Includes firms in pyramids & no & yes & no & yes \\
\hline
\end{tabular}

Note: Categories are defined as in Table 3. Subsamples are smaller because we do not have stock returns for all firms listed in that table. Numbers in parenthesis are probability levels from t-tests. Numbers below them are sample sizes. Boldface type indicates significance in a one-tailed t-test at $10 \%$. The cumulative abnormal return is for all trading days from November 10, the date of the first poll questioning the Liberal lead, through to November 21 1988, the first trading day after a surprise Conservative majority government was returned. Cumulative abnormal returns are returns minus the value weighted returns of all other firms in the 3 digit industry. Using equal weighting gives similar results. - This panel contains coefficients and p-levels for $\delta$, a dummy variable set to one if the firm is in subsample 1 and zero if it is in subsample 2., in the ordinary least squares regression $C A R_{i}=\beta_{0}+\beta_{1} \log \left(\right.$ age $\left._{i}\right)+\beta_{2} \log \left(\right.$ sales $\left._{i}\right)+\beta_{3} \delta_{i}$. 


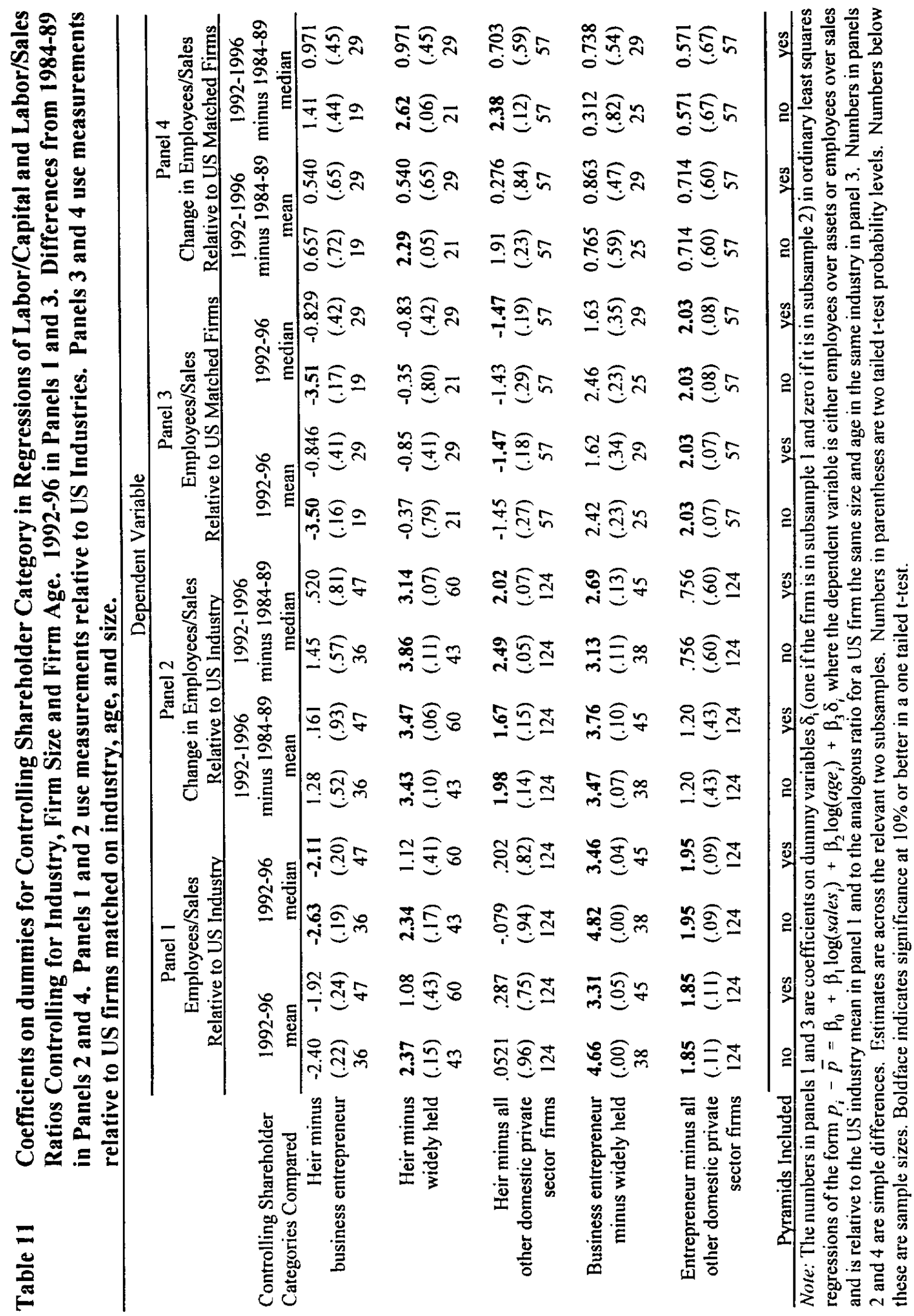




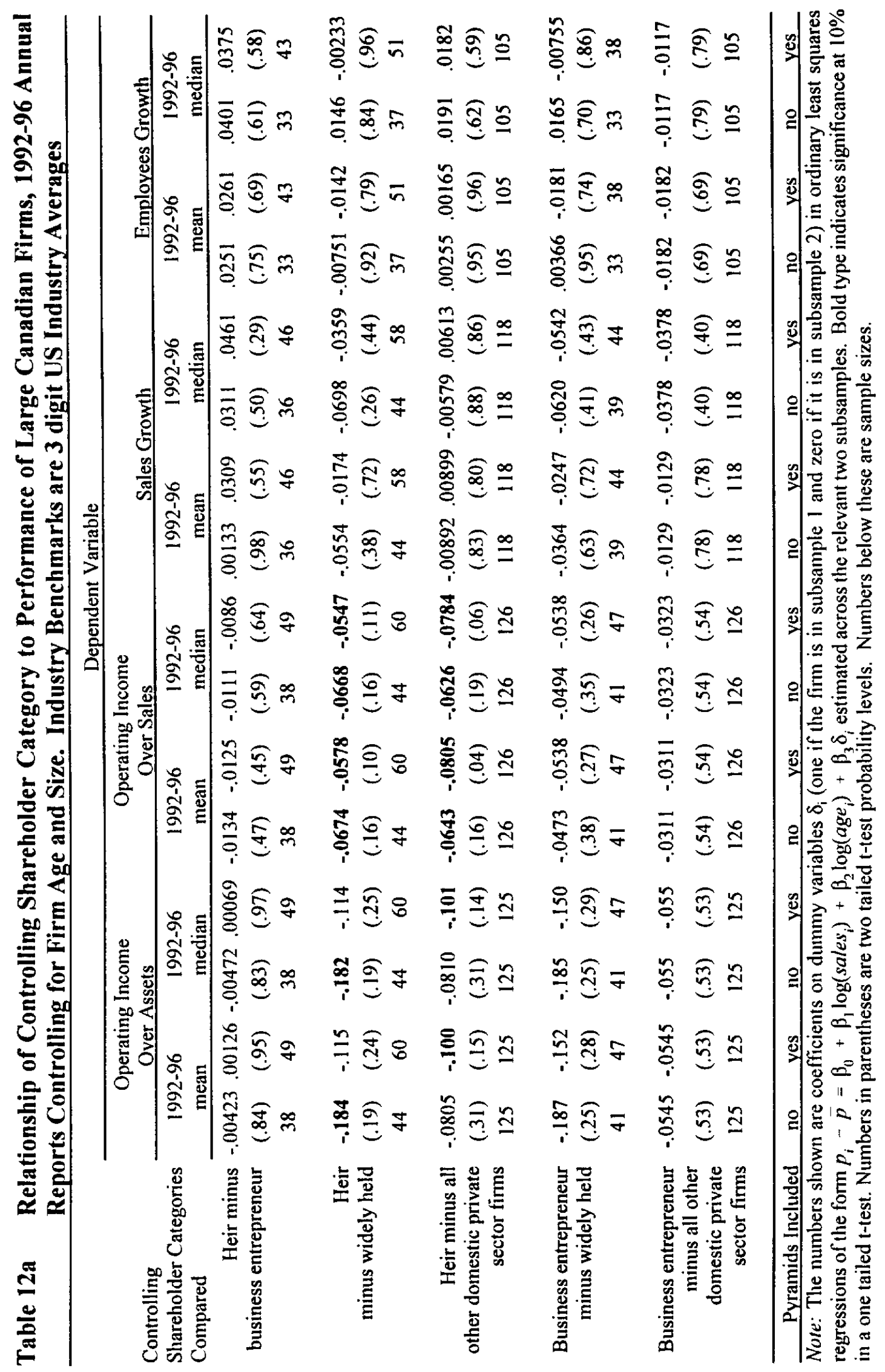




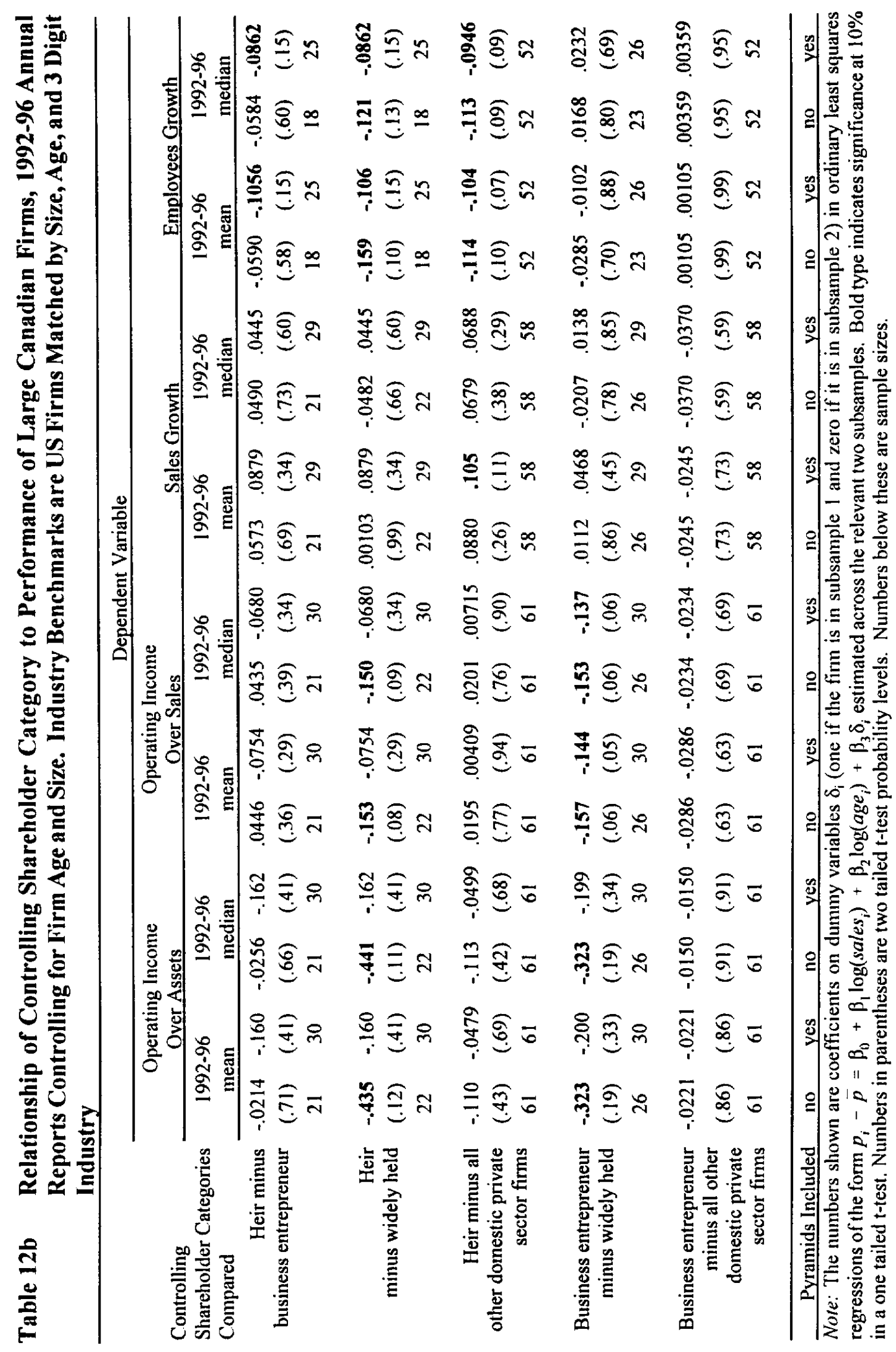


Table 13 Transition Matrix for Large Canadian Firms Relating Controlling Shareholder Description in 1988 to Controlling Shareholder Description in 1994

\begin{tabular}{|c|c|c|c|c|c|c|c|c|c|c|c|}
\hline \multirow[b]{2}{*}{1994 controlling shareholder type } & \multicolumn{10}{|c|}{$\begin{array}{l}1988 \text { controlling shareholder type } \\
\text { (see left table margin for definitions) }\end{array}$} & \multirow{2}{*}{$\begin{array}{c}\text { Changes } \\
\text { into } 1994 \\
\text { Category } \\
\end{array}$} \\
\hline & a & $\mathrm{b}$ & c & d & e & $f$ & $\mathrm{~g}$ & $\mathbf{h}$ & $\mathrm{i}$ & $\mathrm{j}$ & \\
\hline a. heir & 8 & 1 & & & & & & & & & 1 \\
\hline b. business entrepreneur & & 38 & & & & & & & & & 0 \\
\hline c. no controlling shareholder (widely held) & 4 & 4 & $(x)$ & 2 & 1 & 5 & 3 & 4 & & & 23 \\
\hline d. other individual or family & 2 & & & 19 & & & 1 & & & & 3 \\
\hline e. investment fund & & 2 & & 1 & 3 & 2 & 1 & & & 1 & 7 \\
\hline f. widely-held Canadian parent firm & & & 1 & 1 & & (3) & 1 & & & & 3 \\
\hline g. foreign parent firm & & 1 & & & 1 & 1 & 2 & 1 & & & 4 \\
\hline h. government & & & & & & & & 18 & & & 0 \\
\hline i. coop & 1 & & & & & & & & - & & 1 \\
\hline j. labor & & & 1 & & & & & & & 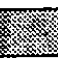 & 1 \\
\hline k. bankruptcy & & 1 & & 3 & 1 & & & & & & 5 \\
\hline 1. acquired & & & 3 & 1 & & & 1 & & & & 5 \\
\hline m. unknown & 1 & & 1 & 2 & & & & & & & 4 \\
\hline Total in Category for 1988 & 44 & 27 & 53 & 29 & 6 & 14 & 49 & 23 & 0 & 1 & \\
\hline
\end{tabular}

Sample is firms in the 1988 Financial Post 500 for which accounting and ownership data are available. 


\section{DATA APPENDIX}

\section{International Data}

Our country-level sample begins with all countries having 1997 GDP greater than US\$1 billion. We drop post-socialist economies such as China, the Czech Republic, Hungary, Poland and Russia; economies subject to economic sanctions such as Cuba, Iran, and Iraq; the oil sheikdoms Bahrein and Brunei; the tax havens Liechtenstein and Luxembourg; Ethiopia, Kuwait, and Lebanon, which are undergoing post-war reconstruction; Sri Lanka and the Democratic Republic of the Congo, which are currently experiencing civil war; and Bangladesh, Egypt, El Salvador, Ghana, Jordan, Kenya, New Zealand, Nigeria, Saudi Arabia, Syria, Tanzania, and the United Arab Emirates because of missing data. The final sample consists of Argentine, Australia, Austria, Belgium, Brazil, Canada, Chile, Colombia, Denmark, Ecuador, Finland, France, Germany, Greece, Hong Kong, Iceland, India, Indonesia, Ireland, Israel, Italy, Japan, Korea, Malaysia, Mexico, the Netherlands, Norway, Peru, the Philippines, Portugal, Singapore, South Africa, Spain, Sweden, Switzerland, Taiwan, Thailand, Turkey, the United Kingdom, the United States, and Venezuela. We exclude the United States and the United Kingdom from our sample on the grounds that their corporate ownership structures are highly atypical, in that their large listed companies are predominantly directly held by small shareholders (La Porta et al. 1997).

Data on billionaire wealth is from Forbes magazine's annual list of billionaires for 1993. We use Forbes' description of the billionaires to classify them as heirs, entrepreneur-founders and heir-entrepreneurs (people who inherited huge fortunes but greatly increased them). We double check in the 1994 to 1997 Forbes issues to verify the accuracy of our classification of each billionaire. (The 1997 Forbes explicitly classifies billionaires as self-made or not.) Members of 
billionaire political dynasties (obtained from Forbes 1997) are classified as heirs. Dropping them does not change the results. Ambiguous classifications by Forbes are cross checked with Who's Who. If they are still ambiguous, these billionaires are assigned to a fourth "probably heir" category. Including them and/or the "heir-entrepreneurs" in the heir category does not change the results.

Our GDP and population data are from the World Bank, with data for Taiwan obtained from the website of that country's government. Our data on investment rates and education (human capital) are from the World Bank Growth Data used by, e.g., Barro and Lee (1996). The political economy variables are from Holmes, Johnson and Kirkpatrick (1997).

Univariate statistics for these variables are shown in Table A1.

\section{Table A1: Univariate Statistics for Country-Level Data}

\begin{tabular}{lcccc}
\hline Variable & Mean & $\begin{array}{c}\text { Standard } \\
\text { Deviation }\end{array}$ & Minimum & Maximum \\
\hline Economy Characteristics & & & & \\
$\quad$ Growth rate in GDP (\%) & $4.11 \%$ & 2.50 & -0.233 & 9.03 \\
Per capita GDP (US\$ X 1,000) & 13.5 & 10.7 & 0.314 & 38.1 \\
$\quad$ Capital investment rate (\%) & 22.3 & 6.20 & 12.9 & 36.7 \\
$\quad$ Average years of education & 6.82 & 2.18 & 3.05 & 10.4 \\
Economy Capital Ownership Structure & & & & \\
$\quad$ Business entrepreneur billionaire wealth over GDP & $1.47 \%$ & 3.35 & 0.000 & 19.3 \\
$\quad$ Heir billionaire wealth over GDP & $1.96 \%$ & 3.23 & 0.000 & 15.8 \\
Political Economy Variables (1 = low, 5 = high) & & & & \\
$\quad$ Level of govt. intervention & 2.38 & 0.990 & 1.000 & 5.00 \\
$\quad$ Extent of regulations & 2.72 & 0.759 & 1.000 & 4.00 \\
$\quad$ Trade barrier height & 2.64 & 1.11 & 1.000 & 5.00 \\
$\quad$ Foreign direct investment barrier height & 2.21 & 0.570 & 1.000 & 3.00 \\
$\quad$ Index of overall tax burden & 3.96 & 0.920 & 1.500 & 5.00 \\
$\quad$ Innovation Rate Variables & & & & \\
$\quad$ Private sector R\&D over GDP & $.406 \%$ & 0.517 & 0.000 & 1.88 \\
\hline
\end{tabular}

Note: The sample is 39 countries, as listed in Table 1 except for private sector R\&D over GDP, which is available for only 34 countries. Sample excludes the United Kingdom and United States.

* Billions in wealth over trillions of GDP.

\section{Canadian Data}

Our sample of large Canadian firms begins with the Financial Post 500, the largest 500 
firms in 1988, ranked by sales as listed in the Financial Post magazine. Ownership and minimal financial data are available for 246 of these.

Ownership data is from the Financial Post Survey of Industrials and the Financial Post Survey of Energy and Mining Companies. This data is cross checked against Statistics Canada's Directory of Intercorporate Ownership for 1989. Inconsistencies are resolved by checking proxy statements. For each firm, the total number of shareholder votes is calculated assuming that all warrants, convertibles and stock options have been exercised. The total number of votes controlled by the largest shareholder is calculated in a similar way. This is divided by the total number of votes to obtain the largest shareholder's voting power. We define a firm as having a dominant shareholder if the largest single shareholder owns or controls more than $20 \%$ of total voting rights. Where more than one shareholder is listed as having voting control over a trust we assign each an equal proportion of the votes. Firms with no dominant shareholder are classified as widely held. The name of the largest shareholder among those with stakes exceeding $20 \%$ is determined. Information from corporate histories, proxies, the Blue Book of Canadian Business, and Who's Who allow us to determine the name of each firm's founder. If the founder and the current major dominant shareholder are the same, we call the firm entrepreneur-controlled. If the current dominant shareholder has the same last name as the founder, we define the firm as a heir-controlled.

Financial data are from the Toronto Globe and Mail's InfoGlobe database and are available for 200 of our firms. We compare these Canadian firms with US industries and with US firms matched by industry, sales and age (see details below). U.S. financial data is from the Standard and Poor's Compustat database. We adjust fiscal year definitions of our Canadian firms to correspond to Comnpustat's convention that annual reports dated before June 15 of year $t$ are defined as year $t$-1 data. 
All Canadian dollar amounts are converted to US dollars. Monthly exchange rates are noon averages from the "Bank of Canada Review" quarterly issues. Using the average of the twelve monthly averages ending with the month of the fiscal year end, Canadian figures are converted to US dollars. Numbers for Canadian companies that report in US dollars not adjusted.

Industry classifications are made using the Standard Industrial Classification (SIC) codes system of Standard and Poor's Compustat data base. U.S. rivals are defined as all U.S. firms belonging to the same industry (defined by 3 digit SIC codes) as the Canadian firm. For each set of U.S. rivals we construct an industry profit rate by adding up the total operating income of the firms and dividing this by the total of their sales. Many of our Canadian firms are not included in Compustat. For these, an industry classification was found in Dunn and Bradstreet's Canadian Directory. Since the industry codes used by Dunn and Bradstreet are not identical to those used by Compustat, a conversion table was worked out using firms listed in both. The first three industry codes (in declining importance by sales in that industry) from Dunn and Bradstreet were used in deriving the conversion table. US matched pair firms are the US firms in the same three digit industry as the Canadian firm in question for which the sum of the absolute values of the percentage differences in sales and firm age are minimized.

Operating income is defined as earnings gross of depreciation, interest and tax payments. This is scaled by either total assets or total sales. Sales growth is measured in US dollars for Canadian and US firms. To reduce distortions caused by extraordinary events or macroeconomic factors, we smooth our measure by taking the median of the industry adjusted profit rates between 1984 and 1989 for each Canadian firm. The exchange rates at the beginning and end of this period are almost identical at about $C \$ 1.20$ per US dollar, despite swings in intermediate years. Since the median is usually calculated from six observations, an even number; after ordering the observations 
we define their median as the half-way point between the third and fourth observations. We use the logarithm of total 1989 sales to measure firm size, and the logarithm of the number of years since the firm's first incorporation date to measure firm age. This date is obtained from the Blue Book of Canadian Business, Who's Who, financial reports and corporate histories.

Missing from this list of variables is a measure of stock market valuation. Many of the Canadian firms we study have one or more classes of equity that do not trade publicly. It is not possible to reliably estimate variables such as $q$ ratios for these firms. Excluding these firms would result in a very unrepresentative picture of the Canadian economy. Also, valuing firms that are included in control pyramids can be problematic, as shares in other firms constitute large fractions of their assets.

Univariate statistics for all our variables are given in Table A2.

Table A2 Univariate Statistics for Canadian Firm-Level Data

\begin{tabular}{|c|c|c|c|c|c|}
\hline variable & & mean & $\begin{array}{l}\text { standard } \\
\text { deviation }\end{array}$ & minimum & maximum \\
\hline operating income over assets, $1984-89$ & $\begin{array}{l}\text { mean of annual observations } \\
\text { median of annual observations }\end{array}$ & $\begin{array}{l}.0107 \\
.00686\end{array}$ & $\begin{array}{l}.0728 \\
.0592\end{array}$ & $\begin{array}{l}-.170 \\
-.179\end{array}$ & $\begin{array}{l}.616 \\
.180\end{array}$ \\
\hline operating income over sales, $1984-89$ & $\begin{array}{l}\text { mean of annual observations } \\
\text { median of annual observations }\end{array}$ & $\begin{array}{l}.0122 \\
.0101\end{array}$ & $\begin{array}{l}.0887 \\
.0898\end{array}$ & $\begin{array}{l}-.169 \\
-.198\end{array}$ & $\begin{array}{l}.445 \\
.501\end{array}$ \\
\hline growth in sales, 1984-89 & $\begin{array}{l}\text { mean of annual observations } \\
\text { median of annual observations }\end{array}$ & $\begin{array}{l}.0931 \\
.0297\end{array}$ & $\begin{array}{l}.412 \\
.178\end{array}$ & $\begin{array}{l}-.316 \\
-.4367\end{array}$ & $\begin{array}{l}4.85 \\
1.40\end{array}$ \\
\hline growth in number of employees, $1984-89$ & $\begin{array}{l}\text { mean of annual observations } \\
\text { median of annual observations }\end{array}$ & $\begin{array}{l}.142 \\
.0384\end{array}$ & $\begin{array}{l}.716 \\
.282\end{array}$ & $\begin{array}{l}-.742 \\
-.742\end{array}$ & $\begin{array}{l}8.40 \\
2.35\end{array}$ \\
\hline $\begin{array}{l}\text { date of first incorporation } \\
\text { total sales in billions of } 1988 \text { US dollars } \\
\text { percent of votes controlled by largest sha }\end{array}$ & eholder with $20 \%$ or more & $\begin{array}{l}1945 \\
1,111 \\
46.1\end{array}$ & $\begin{array}{l}33.3 \\
2,167 \\
29.8 \\
\end{array}$ & $\begin{array}{l}1670 \\
.0399 \\
0 \\
\end{array}$ & $\begin{array}{l}1987 \\
15.6 \\
100\end{array}$ \\
\hline
\end{tabular}

